\title{
2h)
}

ESTUDIOS LITERARIOS

\section{AL-MASĀLIK WA-L-MAMĀLIK: PRECISIONES ACERCA DEL TÍTULO DE ESTAS OBRAS DE LA LITERATURA GEOGRÁFICA ÁRABE MEDIEVALY CONCLUSIONES ACERCA DE SU ORIGEN Y ESTRUCTURA}

\author{
AL-MASĀLIK WA-L-MAMĀLIK: PRECISIONS CONCERNING THE TITLE OF THESE \\ TREATIES OF GEOGRAPHICAL ARABIC LITERATURE AND CONCLUSIONS ABOUT ITS \\ ORIGIN AND STRUCTURE
}

FrANCISCO FrANCO-SÁNCHEZ

Universidad de Alicante

ffransan@ua.es

Recibido. 18-12-2017

Aceptado: 15-05-2018

\section{RESUMEN}

El primer objetivo de este estudio es repasar lo que se ha escrito sobre los libros que llevan el título de Kitāb al-masālik wa-l-mamālik para mostrar cómo en el origen de este grupo de obras (más que "género") hay un modo expositivo común a todos, heredado de los ruteros o itineraria romanos. Un segundo objetivo es presentar cómo el éxito de estas obras hizo que por utilizar una etiqueta común como al-Masālik wa-l-Mamālik otros tratados copiaron y reprodujeron esta etiqueta en compendios que ya no eran desarrollos de los itinerarios primigenios, sino auténticas obras de geografía descriptiva, con importante carga de información histórica.

Palabras clave: Geografía árabe medieval, Itinerarios romanos, Kitāb al-masālikwa-lmamālik, Literatura árabe medieval.

\section{ABSTRACT}

The first objective of this study is to review what has been written about the treaties bearing the title of Kitāb al-masālik wa-l-mamālik to show how at the origin of this group of works (rather than 'genre') there is an expositive mode common to all, inherited from the Roman itineraries. A second objective is to present how the success of these works meant that, by using a common label such as al-Masālik wa-l-Mamälik, other treaties copied and reproduced this label in works that were no developments of the original itineraries, but authentic works of descriptive geography, with an important historical information load.

Keywords: Medieval Arabic geography, Roman itineraries, Kitāb al-Masālik wa-lmamālik, medieval Arabic literature. 


\section{INTRODUCCIÓN HISTORIOGRÁFICA ${ }^{1}$}

Hace tiempo que fijamos la atención en un tipo de obras de la geografía árabe islámica medieval tradicionalmente conocido y etiquetado como (Kitāb) al-masālik wa-l-mamālik (que se suele abreviar con el acrónimo $K M M$ ), que se han presentado tradicionalmente como un "género" unitario, y vamos a comenzar a difundir el resultado de las investigaciones que estamos desarrollando en los últimos años. Comenzaremos por hablar de la etiqueta o denominación del género y de sus no tan lejanos antecedentes greco-romanos y persas.

Este tipo de obras geográficas árabes escritas durante la segunda mitad del siglo IX e.C., y el s. X, así como otros epígonos que reutilizaron este título, o elaboraron otros títulos derivado del mismo, tenían en común el objetivo de escribir una descripción del mundo conocido en su época; por su notable repercusión en todos los apartados de la cultura árabe, ya desde su misma época, tuvieron un notable eco y difusión, siendo pronto conocidos en Oriente.

Decenas de notables investigadores desde el s. XIX se han fijado tanto en los textos de este tipo de obras, como en los mapas y cartografía anexa que llevan algunos de ellos, de modo que la bibliografía al respecto es inmensa. A pesar de todo, muchos de ellos no han hecho sino repetir miméticamente lo que dijeran Sezgin, De Goeje y los autores de las biografías de sus diversos autores en la The Encyclopaedia of Islam [Encyclopédie de l'Islam] en sus dos ediciones $\left(E I^{1}\right.$ y $\left.E I^{2}\right)$. Puede parecer una osadía intentar hacer aportaciones nuevas al conocimiento académico de un ámbito sobre el que tanto sabio y estudioso de la geografía árabe medieval ha escrito alguna vez, y sobre el cual hay centenares de libros y artículos escritos desde mitad del siglo XIX. La inmensa bibliografía se muestra como el más abrupto escollo cuando deseamos profundizar en su conocimiento, puesto que es una bibliografía tan abundante como reiterativa en ideas asentadas como dogma.

Desde el mismo s. III H./IX e.C. en que surgen las primeras obras de este tipo, la etiqueta de (Kitāb) al-masālik wa-l-mamālik tuvo tal fortuna que será copiada y utilizada en ilustres obras de geografía descriptiva o de genero mixto geográficohistórico en la edad media árabe. Este éxito ya consolidado en el pasado de la citada etiqueta será asumido por los investigadores europeos desde el 1800, en que William Ouseley publica su traducción inglesa de la obra de Ibn Hawqal, que presenta con su título de Kitāb masālik wa-mamālik tașnīf Ibn Hawqal. The Oriental Geography of Ebn Haukal, an Arabian Traveller of the Tenth Century, explicando en su introducción cómo la formula será luego copiada en sus títulos por otros autores árabes posteriores (Ibn Hawqal Ouseley: IV-VI).

La reutilización de $K M M$ como título ha sido entendido como un intento de las obras posteriores así tituladas de parecerse a las primeras obras de geografía

1 Este trabajo se ha desarrollado en el marco de Proyecto de Investigación: Autobiografía y cartografía como proyecciones identitarias en el islam clásico, Ref. FFI2014-58636-P, concedido por la Secretaría de Estado de Investigación, Desarrollo e Innovación del MINECO. 
árabe, las más antiguas del género, siendo las obras posteriores un enriquecimiento de la fórmula que las alejará del modelo inicial. Esta idea de la continuidad de un género más o menos uniforme ha sido expresada claramente por Charles Pellat en el artículo de la $E I^{2}$ que dedica a "Al-Masālik wa-l-Mamālik"; recuerda con acierto que esta etiqueta le fue dada por R. Blachére en la primera edición de 1936 de sus Extraits des principaux géographes arabes du Moyen Âge: Blachère reunió a las obras que llevaban este título, partiendo de la de al-Iștajrī, sumándole el Kitāb al-buldān de al-Ŷa'qūbī, K. șuwar al-aqālīm de al-Baljī; KMM de al-Ișțajrī, así como las obras de Ibn Hawqal, al-Muqaddasī y una obra de al-Idrīsī que afirma que no parece haberse conservado (Rawd al-uns). La segunda edición de estos Extraits, corregida con Henri Darmaun y editada en 1957, es la que extenderá esta presentación pedagógica como dogma hasta la fecha, y no hemos visto que este dogma haya sido cuestionado en ningún momento. En esta misma línea argumental, André Miquel amplía la información de estas obras en cuanto a género, en un largo capítulo de su tomo I que titula como "L'avènement d'une véritable géographie humaine: les masălik wal-mamālik et l'étude de la terre des hommes", en el cual estudia las obras de al-Iștajrī, Ibn Hawqal, añade la de al-Muhallabī (m. 380/99o) y al-Muqaddasī como el apogeo, lo mismo que de pasada, como accidentalmente, también las obras de al-Bakrī y alIdrīsī (Miquel 1967: 267-330).

Ch. Pellat matiza que esta manera de presentar los $K M M$ por parte de Blachère era meramente didáctica. ${ }^{2}$ Por otro lado, Kramers en el artículo "Djughrāfiyā" que escribió para la $E I^{1}$ hace entrar en el mismo "grupo literario" a Ibn Jurradād̄bih, alIștajrī, al-Sarajsī, al-Ya‘qūbī, Ibn al-Faqīh, Ibn Rustah, Qudāma, al-Ŷāhiż, y al-Ŷayhānī, mientras que trata separadamente a la "escuela de al-Baljī" (Franco-Sánchez 2005b). S. Maqbul Ahmad se encargó de la redacción de esta entrada sobre la "Djughrāfiyā" en la segunda edición de la $E I^{2}$; a diferencia de Pellat, hace dos grupos de obras geográficas en esta época, evitando la clasificación directa de un grupo (o "género") como del $K M M .^{3}$ Mientras que Pellat acaba concluyendo que "A pesar de una cierta convergencia, las clasificaciones, como podemos ver, son notablemente diferentes y requieren que tengamos cuidado al manejar el concepto de masālik wa-mamālik", ${ }^{4}$ es Maqbul Ahmad el único que ha discrepado de este tipo de presentación de las obras de $K M M$, apuntando la mayor complejidad del asunto (puesto que habitualmente

2 "C'est dans un dessein purement didactique que Blachère avait distingué du reste de la littérature géographique le genre des masâlik wa-mamâlik, dont les limites sont loin d'être tranchées» (Pellat $\left.E I^{2}: 625\right)$.

3 Así en $E I^{2}$ (II: 593b), aunque hace una clara alusión a las obras de al-masālikwa-l-mamālik, divide la literatura geográfica en dos grupos: la "escuela iraquí” (Ibn Jurradādِbih, al-Ișțajrī, al-Ya'qūbī, Ibn alFaqīh, Qudāma, Ibn Rustah, al-Mas'ūdī y al-Ŷayhānī. Y por otro lado, la "escuela de al-Baljı̄”, formada por éste, al-Ișțajrī, Ibn Ḥawqal y al-Muqaddasī.

4 "En dépit d'une certaine convergence, les classifications, on le voit, sont sensiblement différentes et engagent à user de quelque prudence dans le maniement du concept de masâlik wa-mamâlik» (Pellat $\left.\mathrm{EI}^{2}: 625 \mathrm{~b}\right)$. 
solo se consideran en cuanto obras escritas y se olvida la cartografía asociada, tema importante y que no se ha de dejar de lado).

Ibn Hawqal, siendo joven, expresa su voluntad de emprender un viaje para recoger todos los datos posibles del mundo; "en el curso de mis viajes ni el libro de

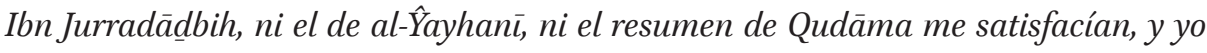
pido perdón a Allāh pero la lectura de estas obras me absorbía tanto que yo dejaba de cultivar otras ciencias útiles y de practicar los deberes imperiosos" (De Goeje BGA II: 235). Está claro que él pone énfasis en la renovación de los conocimientos previos, presentando su obra como renovadora.

Con la excepción de al-Idrīsī estos autores en sus obras dejan de utilizar la clásica división de origen griego en "aqālìm", ${ }_{5}^{5}$ emplean la más útil de mamlaka (pl. mamālik) en el sentido de 'región, provincia'. De este modo, estos tratados describen los mamālik de cada zona del mundo. Dentro de cada mamlaka se enumeran los itinerarios (masālik 'caminos') que la atraviesan y las localidades por las que pasa, con quién comunica ese camino, las distancias y los hombres que habitan a lo largo del mismo. Se consignan todos los datos de importancia itineraria de cada país y luego se pasa al siguiente país. Contrastando con los secos manuales de $a d a b$, estas obras tienen también un cierto aspecto literario, puesto que de cada una de las regiones hallamos narraciones históricas y se recogen relatos diversos, siendo en la obra de al-Bakrī donde encontramos este aspecto más desarrollado.

Desde que la etiqueta Al-Masālik wa-l-Mamālik fuera asignada a un tipo de obras de "literatura geográfica" ${ }^{6}$ en 1937 por Kramers $\left(E I^{1}\right)$ y luego fuera consagrada en la conocidísima obra de Blachère y Darmaun $(1934 ; 1957)$ se ha creado una idea fija sobre la misma, avalada por estos ilustres investigadores arabistas, una presentación repetida con asiduidad (Mu'nis 1967). Con posterioridad, André Miquel (1967; 1975; 1997; 1983) y su escuela (Cornu) escribieron mucho sobre este tema, pero ellos casi cerraron el interés por estas obras en cuanto a conjunto. F. Roldán y R. Valencia (1988), más recientemente, hicieron un excelente resumen sobre el tema, con la finalidad de recordar que al-Bakrī , al-'Udrī y el enciclopedista oriental al-Qazwīnī son deudos de esta estructura expositiva.

La mayor innovación reciente ha venido del estudio de la cartografía asociada a estas obras, de modo que se ha recordado que si bien los textos de esta "escuela del Atlas del islam", o también de "al-masālikwa-l-mamālik" son fácilmente relacionables con sus autores, en cambio, se hacía necesario un estudio de la cartografía contenida

5 Los aqālìm 'climas' son divisiones teóricas griegas, al modo de paralelos, que definían 7 paralelos encima del Ecuador y dos por debajo del mismo.

${ }^{6}$ Entendemos que se debe diferenciar entre la "Geografía", entendida como disciplina científica (cuyas aportaciones en diversos de sus ámbitos -geografía astronómica, cartografía- fueron fijando y precisando el conocimiento de las regiones y localidades del globo), en contaposición al concepto de "literatura geográfica", que es inclusivo tanto de las obras de que en época medieval se presentaron como Geografía -ruteros, descripciones de geografía humana, económica-, como también de todas las que incluyen información geográfica de diverso tipo (sería una geografía entendida en su sentido más amplio, como una parte de la Arabische Litteratur). 
por los manuscritos de estas obras, porque Konrad Miller (1926-7) ya evidenció y dio a conocer la riqueza cartográfica y la importancia de la imagen del mundo que transmitían. Esto primeramente fue analizado en un interesante estudio por G. R. Tibbets (1992), quien destacó la relevancia de los diversos estadios en la evolución de la representación del mundo islámico conocido que muestran estos mapas de la también conocida como "escuela de al-Balji”". Más recientemente K. C. Pinto (2016), ha analizado la pervivencia de esta cartografía deuda de los KMM en época otomana y safaví. En el estudio de Tibbets se publica un diagrama explicativo de la génesis de los manuscritos de esta escuela, que reproducimos por su evidente interés:

DIAGRaMa MOSTRANDO LA RELACIÓ́N ENTRE LOS TEXTOS DE LA “ESCUELA DE AL-BALJ"

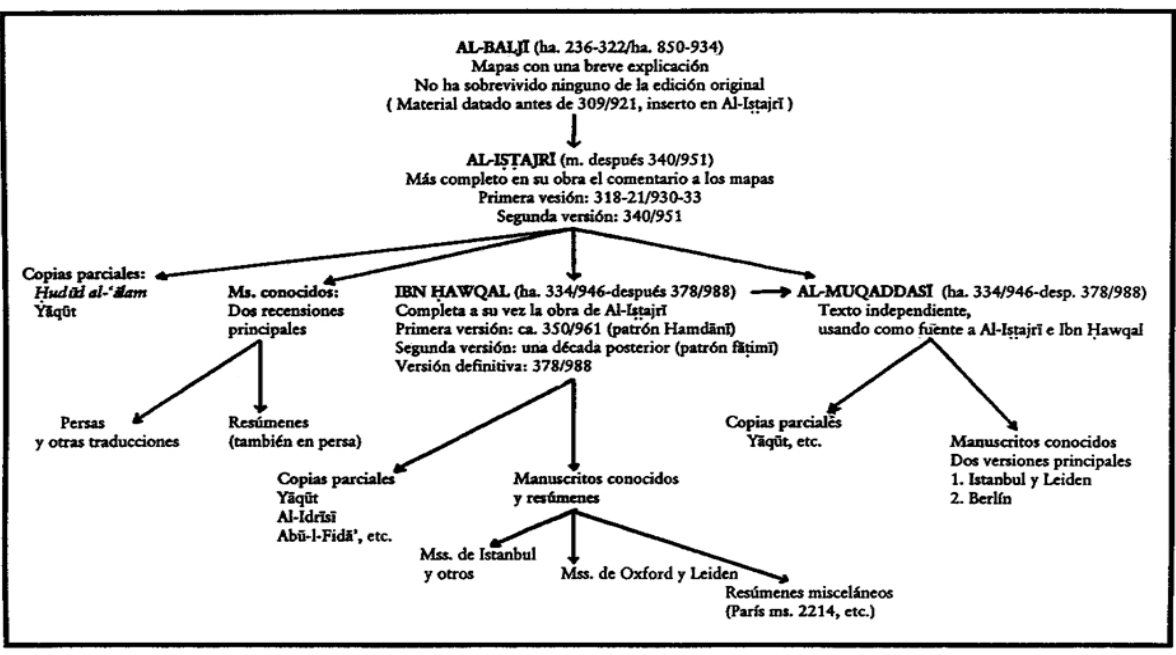

Figura 1: Diagrama mostrando la relación entre los textos de la "Escuela de al-Balji" (Tibbets 1992: 111, fig. 5.2)

En el presente estudio vamos a presentar las conclusiones de lo que ha sido muchos años de reflexión en torno a una etiqueta identificadora que nunca vimos como tal etiqueta definidora de un "género" uniforme y asociado con las obras árabes medievales que recogen la geografía humana. El primer objetivo es repasar lo que se ha escrito sobre estas obras para mostrar cómo en el origen de este grupo de obras (más que "género") hay un modo expositivo común a todos, heredado de los ruteros o itineraria romanos. Un segundo objetivo es presentar cómo el éxito de estas obras hizo que por utilizar una etiqueta común como al-Masālik wal-Mamālik otras obras copiaron y reprodujeron esta etiqueta en obras que ya no eran desarrollos de los itinerarios primigenios, sino auténticas obras de geografía humana, con alta carga de información histórica. 


\section{LA DERIVA DE UNA ETIQUeTA: DE Título EXITOSO A “GÉnero geográfico”}

\subsection{Un título poco común como tal título de obra árabe}

Alfonso Carmona en sus dos artículos sobre la estructura de los títulos de las obras árabes de época clásica (1987-89; 200o), concluye que la norma es que los árabes etiquetaran sus producciones con un título cuya estructura tradicional fuera bipartita, o bimembre, y por lo común rimada; habitualmente se componía de dos partes, dos hemistiquios que rimaban entre sí y han de ser considerados con significación independiente, ambos articulados en base a un gozne que solía ser la partícula $f \iota$, aunque también $\min$, li-, etc. ${ }^{7}$ El primero de los hemistiquios lo formaban de 2 a 4 palabras que tenían como fin que su musicalidad (o forma poética) fuera asociada a esa obra; su finalidad es dar pie a la rima, siendo una bella expresión sin relación comúnmente con el sentido o contenido de la obra, destinada a ser memorizada fácilmente y a denominar y hacer que se recuerde la obra en el futuro. ${ }^{8}$ El segundo hemistiquio era generalmente más largo y sí que aludía más explícitamente al contenido de la obra.

Ésta es, pues, la primera función de la rima: establecer un título breve y un "subtítulo" o ampliación del título corto. Tras la primera de las dos palabras que riman hay que fijar, por lo tanto, una especie de cesura rítmica que implica un corte en el sentido; las partes separadas por la "cesura" forman unidades independientes, sintagmas con sentido completo (Carmona 2000: 86).

Una clase diferente de títulos son los que Carmona denomina "sin ornato", cuya finalidad es la de presentar un rótulo descriptivo del contenido, tal y como se suele hacer en la actualidad. Es una fórmula poco utilizada en este período "y será suficiente con que citemos, por último, como bello exponente de este género de títulos, los varios libros de geografía denominados Kitāb al-masālik wa-l-mamālik (Libro de los Caminos y los Reinos) (1987-89: 182)". Este título "utiliza el recurso literario del taŷnis, de la paronomasia, sin establecer dos partes en el nombre del libro" (2000: 86), esto es: dos palabras con semejanza fonética que únicamente se diferencian por una consonante: masālik y mamālik.

De este modo, encontramos un tipo de obras muy determinado, que desde su origen tuvieron una etiqueta tan funcional como atípica entre los títulos de obras

7 A. Carmona (1987-89; 200o) presenta resultados muy parecidos a los del estudio del alemán Arne A. Ambros (1990) quien, tras estudiar un corpus de 1.69o títulos de obras árabes compilados a partir del conocido repertorio de Brockelmann, clasificó los tipos de estructura sintáctica de los títulos, así como de los términos árabes más frecuentes empleados para su composición, estudiando su frecuencia y clasificándolas por campos semánticos.

8 Respecto a su traducción escribe: "la mayoría están estructurados en dos partes unidas con la preposición fi a modo de bisagra. La significación de esta partícula puede ser tanto la de "en, dentro de" como la de "sobre, acerca de"; en este caso, es la segunda acepción la que hay que retener." (198789: 182); "la preposición $f \imath$ no está directamente vinculada a ninguna de las palabras del título corto, sino que es una extensión de kitāb, risāla, etc. (implícitos o explícitos) e indica la materia" (2000: 87). 
árabes medievales. Quizás esto se deba a que la mayor parte de ellas surgieron en un entorno persa y por ello buena parte de este tipo de obras, incluso otras con títulos diferentes al de $K M M$ (como las de al-Ya‘qūbī o Ibn Ḥawqal), aunque hayan sido escritas en árabe, tienen un título funcional y escueto, sin la estructura bimembre tradicional de las obras árabes. Quizás a ello se deba su éxito, al conseguir la automática identificación de $K M M$ como obra de geografía descriptiva. Será, por tanto, rótulo que será copiado y lo encontraremos en bastantes obras.

Ciertamente esta etiqueta la hallaremos en muchas obras desde que la utilizara por vez primera. Incluso obras como las de Ibn Hawqal, con título diferente, serán conocidas con éste de $K M M$ como segundo título, a veces usado como denominación principal, otras veces como secundaria. Lo explica muy bien Alfonso Carmona:

La razón de esa estructura del título árabe es proporcionar en la primera parte una expresión basada en una bella imagen que fuera fácil de recordar, para que sirviera como título corriente. Sin embargo, bien pronto, las palabras empleadas en unos rótulos empezaron a ser repetidas en otros y se abusó de unas mismas imágenes, llegando con gran frecuencia a tener varios libros el mismo rótulo. Por lo tanto, la finalidad principal de dicha estructura, que era la de diferenciar más fácilmente unas obras de otras y retener mejor en la memoria sus títulos, se vio en parte obstaculizada por una excesivamente mimética aplicación del sistema heredado.

Los autores denominaban sus obras copiando unos de otros palabras prometedoras y cargadas de resonancias (y sin duda prestigiadas al haber sido utilizadas por importantes escritores) (1987-89: 184).

Ciertamente esta fue la razón por la cual a partir del éxito de una primera etiqueta o título, éste se vuelve a utilizar nuevamente en obras similares que buscan aprovecharse de la estela de su fama. En los títulos con dos hemistiquios rimados, es el primero de ellos, la primera parte del rótulo la que suele ser copiada por otras obras, sin que ello implique que sean obras de géneros o características similares.

En el caso que nos ocupa, el rótulo de al-masālikwa-l-mamālik no se corresponde a esta estructura bimembre del título, sino que todo él constituye una etiqueta unitaria. De modo que, cuando se copia, se hace en su totalidad. Las variantes vendrán posteriormente cuando convierten el rótulo en bimembre, convirtiendo en dos partes diferenciadas sus dos elementos originales, unidos por la conjunción copulativa wa-: masālik, 'caminos, itinerarios', y mamālik 'reinos', añadiéndoles algunas palabras a cada uno de ellos y, en ocasiones, dotándoles de rima interna. Una traducción literal sería 'Libro de los caminos y los reinos', aunque creemos que es más significativo traducirlo como 'Tratado sobre los caminos y los reinos'.

\subsection{Pero un título de gran éxito}

Tras una completa búsqueda hemos identificado 15 obras con ese título u otros derivados, pero alguno más debió ser escrito. Seguidamente se van a enumerar el 
listado de las obras en cuyos títulos hallamos esta fórmula, ordenados por orden cronológico ascendiente de fecha composición. Se añaden algunos datos específicos sobre su composición, autor y cronología:

§ 1). Kitāb al-masālik wa-l-mamālik, obra incompleta que no pudo concluir Ŷa'far [al-'Abbās] Ibn Aḥmad al-Marwazī (m. 274/887) (GAL S I: 403)99. Según cita Ibn al-Nadīm y recoge de él Yāqūt, fue el primero que compuso una obra inconclusa así titulada. Según refieren, esta obra recogía los itinerarios utilizados por los servicios de correos omeyas y tenía como finalidad servir a las necesidades de la administración. Carecemos de más datos sobre autor u obra.

§ 2). Otra que le disputa a la anterior el haber sido la primera en llevar el título de Kitāb al-masālik wa-l-mamālik es la obra escrita por Aḥmad Ibn al-Ṭayyib alSarajsī (m. 286/899) (Rosenthal 1943), según da noticia al-Mas'ūdī en su Tanbīh (67; Dunlop $E I^{2}$ : 1034). Era un tratado geográfico y no se ha conservado. Entre los muchos discípulos del gran filósofo al-Kindī se menciona a al-Sarajsī, lo mismo que también al-Baljī, el epónimo de una escuela geográfica conocida tanto como "escuela de al-Baljī".

§3). La primera obra conservada, aunque incompleta, es el Kitāb al-masālikwal-mamālik, de 'Ubayd Allāh Ibn 'Abd Allāh Ibn Jurradādِbih (m. 30o/912) (GAL I: 225-6, S I: 404; Van Arendonk EI; Hadj-Sadok $E I^{2}$; Bosworth EIr, Ibn Jurradād̄bih $B G A$ VI; Barbier de Meynard; Sezgin 1992). Es uno de los más antiguos escritores en árabe cuyos escritos hayan perdurado. Su nombre ya indica una procedencia iraní, siendo su familia zoroastriana, él abraza el islam para complacer a un miembro de la poderosa familia de los visires barmakíes (posiblemente Yahyyà Ibn Jālid). De su padre se sabe que fue gobernador del Tabaristān y que consiguió poner bajo la obediencia a determinadas regiones del Daylam. 'Ubayd Allāh nació en Jurasān, siendo lo único seguro, puesto que para las fechas de nacimiento y muerte hay dos posibilidades: 205/820 o 211/826 para el nacimiento, y 272/885 o 30o/912 para la de su fallecimiento. Creció en Bagdad en un ambiente de confort, y allí se formó con los mejores maestros. En la edad adulta él desempeñó primero el cargo de Jefe de Correos e Inteligencia (șăhib al-barìd wa-l-jabar) en la provincia de Ŷibāl, siendo luego promocionado al mismo cargo en la propia capital de Bagdad, y luego de Samarra. Como tal jefe de correos y espías, tenía acceso directo al califa al-Mu'tamid, de quien se convirtió en amigo, compartiendo sus gustos por la vida fácil y frívola, las diversiones, la literatura profana y las artes.

Este origen iraní y las exigencias de su actividad profesional orientaron y condicionaron sus trabajos literarios e históricos. Entre sus obras se destaca un

9 C. Brockelmann afirma literalmente: "Las necesidades de la administración y los servicios postales que sirve el gobierno condujeron a la representación [escrita] de las condiciones principales del tráfico, tal como hiciera Ğa far b. A. al-Marwazi (st. 274/887) en su incompleto [e inacabado] k. al masālik wal-mamālik (Fihrist 15o, Yāqūt, Iršād, II, 400) siendo un [simple] intento. El interés de los principales círculos en Bagdad, sin embargo, todavía se limitaba al mundo islámico". 
Kitāb al-masālik wa-l-mamālik, obra que le ha dado renombre, y que luego fue copiada e imitada por otros autores. Nos ha perdurado una parte de la obra, de modo que hoy tenemos una obra incompleta. Sobre la fecha de su redacción en el pasado hubo una controversia. De Goeje señala que tuvo una primera redacción en 232/846, mientras que la definitiva es de 272/885 (Ibn Jurradād̄bih $B G A$, VI: xx).

§ 4). Al-Ŷayhānī era una de las nisbas de los visires sāmāníes, un imperio sunní iraní que gobernó desde 819 al 999. Uno de los miembros de esta importante familia habría escrito un famoso Kitāb al-masālik wa-l-mamālik, libro que no se ha encontrado, habiéndose asignado tradicionalmente su autoría a un tal Muhammad al-Ŷayhānī (quien habría muerto hacia 287/900) (GAL, I: 228, S. I: 407). Sezgin afirma que fallece después de 367/978 (1994). Ahora bien, los heterogéneos datos que proporcionan las diversas fuentes árabes sobre esta autoría, evaluados con detalle por Ch. Pellat le han llevado a concluir que "se puede avanzar, a título de hipótesis, que el Kitāb al-masālik es una obra familiar, puede ser que comenzada por Muḥammad Ibn Aḥmad (I: Abū 'Abd Allāh Muḥammad Ibn Aḥmad Ibn Naṣr), continuada por su hijo Muḥammad Ibn Muḥammad (II: Abū 'Alī Muḥammad Ibn Muḥammad al-Ŷayhānī) y acabada por su nieto Aḥmad Ibn Muhammad (III: Abū 'Abd Allāh Aḥmad Ibn Muhammad Ibn Naṣr) en los años inmediatamente posteriores a 330/941.2", los tres personajes, pertenecientes a la misma familia, habrían realizado una autoría continuada (Al-Ŷayhanī $E I^{2}: 255$ ). La pluralidad de autores habría sido la causa de la heterogeneidad de nombres y datos sobre ellos que las diversas fuentes han propagado.

Ibn Hawqal hacia el 375/985 declara que había llevado consigo desde el inicio de sus viajes, allá por 331/943, y durante muchos años, los tratados de Ibn Jurradād̄bih, al-Ŷayhānī y de Qudāma (Kramers 1938: 329; Kramers y Wiet 1964: 322) pero él se lamenta haber poseído los dos primeros pues han acaparado su espíritu, mientras que no les muestra ningún aprecio, aunque no deja de explotar la obra de al-Ŷayhānī en lo que respecta al Jurasān (Kramers 1938: 453; Kramers y Wiet 1964: 438). AlMuqaddasī califica a al-Abū 'Abd Allāh al-Ŷayhānī -sin otra precisión onomásticade filósofo y astrólogo, y añade que él había reunido a las gentes que conocen los países del extranjero para interrogarles sobre los estados, sus recursos, sus vías de comunicación, la altura de los astros y la posición que toma su sombra, y que esto era para él el medio de llegar a conquistar estos países y conocer sus recursos; seguidamente le reprocha el que habiendo desarrollado la geografía física de los países descritos, hubiera olvidado datos de importancia (BGA III: 3-4). Según Gardīzī (escribe entre 400-3/1049-52), al-Ŷayhānī se habría dirigido a sus corresponsales, que residían en zonas que iban desde Bizancio a China, y éstos le habrían remitido sus informes por escrito (Al-Ŷayhanī $E I^{2}: 256$ ).

Su $K M M$ no ha perdurado. Debió de completar la obra homónima de Ibn Jurradādbih, con el cual se confunde en numerosas ocasiones. La calidad de sus autores, en una posición administrativa de privilegio para conseguir datos geográficos valiosos, pero sobre todo la riqueza de los datos de esta obra es lo que 
debió interesar tanto a los escritores posteriores para utilizar y copiar su obra en tantas ocasiones.

§ 5). Kitāb al-masālik wa-l-mamālik, de Ibrāhīm al-Ișțajrī al-Fārisī al-Karŷī (m. después 340/951) (Al-Ișțajrī 1870; Miquel $E I^{2}$ 1978). Este 'Tratado sobre los caminos y los reinos' es la segunda obra más antigua que lleva este título, es la primera conservada de la conocida como "escuela de al-Baljī".

Lo curioso es que en ella se recoge la obra de Abū Zayd Aḥmad Ibn Sahl al-Baljī (ha. 236-322/ha. 850-934) Kitāb șuwar al-aqālìm (también conocida por Taqwìm albuldān) (Al-Ișțajrī 1870; Dunlop $E I^{2}$ ), lo cual indica el propio al-Iștajrī en su $K M M$, afirmando que quiso corregirla y ampliarla para darle la entidad que consideraba necesitaba tener una obra geográfica de este carácter. Con ello al-Ișțajrī integra el texto de al-Baljī y lo fusiona con el suyo propio, ampliándolo y corrigiéndolo hasta el punto que la obra de al-Baljī no es posible reconocerla en el KMM resultante. Compuesto a finales del s. IV H./X e.C.

Esta circunstancia, que supone acrecentar y perfeccionar los conocimientos geográficos reunidos por el maestro es la que se pone como el inicio de la se ha dado en llamar "escuela de al-Baljı̄", que recogería la transmisión de textos escritos de carácter geográfico. Esta obra de al-Ișțajrī también incluye una rica cartografía, tanto mundial como regional, y, en cuanto a escuela cartográfica, se ha denominado como "escuela del Atlas del Islam" (Kramers 1932; Tibbets 1992; Franco-Sánchez $2005 \mathrm{~b})$.

Este sentimiento de escuela viene dado a su vez porque Ibn Hawqal refiere en su propia obra cómo, siendo joven, tuvo un encuentro personal con un al-Ișțajrī ya mayor; ${ }^{10}$ en el mismo discuten sobre la cartografía del maestro: encuentra errores en el mapa del Sind coinciden en el del Fārs, al-Ișțajrī aprueba el dibujo de las que hiciera Ibn Ḥawqal del Ādarbayŷān y de la Alta Mesopotamia, pero discrepa del dibujo que Ibn Hawqal hizo respecto a los mapas de Egipto y del Magreb. Como resultado, le comunica al maestro que va a ser él quien perfeccione y corrija su obra: "Hice mejoras en más de un lugar y quise publicarla bajo su nombre. Pero juzgué oportuno no dejar más que el mío en la autoría de la obra" (Ibn Hawqal, Kramers y Wiet 1964: 322; Miquel $E I^{2}$ 1971: 233). Con ello se da una nueva renovación a los conocimientos adquiridos y se reproduce el mismo sistema de viaje, acumulación de experiencia y escritura de una obra fruto del ‘yān, la observación y el personal acopio de noticias y datos, que luego se verterá en la obra escrita. Sobre esta metodología de investigación, sobre observación personal ha escrito interesantes páginas André Miquel (Al-Iștajrī $\left.E I^{2}: 233\right)$. Al-Ișțajrī hizo una larga serie de viajes, que fueron la base para las anotaciones de su obra, pero esta gran virtud metodológica es difícil de comprobar, dado que no refleja apenas nada al respecto en su obra.

10 Tal encuentro se produjo probablemente sobre el $340 / 951 \cdot 2$ (Van Arendonk, $E I: 383$ ) en un lugar que no está claro: en el Sind (según el contexto del relato) o en Bagdad (como es lo más probable) (Ibn Hawqal, Kramers y Wiet 1964: 322). 
De este modo sabemos que conoció la península Arábiga, Iraq, Juzistān Daylam y Transoxiana, y quizás el Sind.

§ 6). Kitāb al-masālik wa-l-mamālik de Muḥammad al-Warrāq (292-363/904973) (Guilliot $E I^{2}$; Pocklington $B A$ ). Originario de Guadalajara (o de Cairuán), se formó en Qayrawān, pero tras la imposición del nuevo régimen šč c de los fāṭimíes, en uno de sus viajes por al-Andalus será invitado a quedarse en la corte por alHakam II, pasando a engrosar la nómina de sus sabios. El insigne historiador andalusí Aḥmad al-Rāzī (m. ca. 344/955) le denomina al-Ta'rījī ‘el Historiador'. En ese sentido, Guilliot apunta que al-Warrāq es una nisba que informa que su padre habría ejercido de copista o de librero, pero que también es muy probable que él mismo fuera bibliotecario en la famosa biblioteca de al-Hakam II (Guilliot $E I^{2}:$ 166); el califa habría encontrado en él un informador competente, particularmente útil en su política exterior en el Magreb.

El mismo califa le hizo el encargo personal de componer un Kitāb al-Masālik wa-l-mamālik, gruesa obra actualmente perdida que trataba específicamente sobre el Magreb. Se han conservado algunos fragmentos de ella por haber sido copiados en otras obras posteriores. Especialmente al-Bakrī lo cita como fuente suya en 24 ocasiones, en conexión con diferentes enclaves norteafricanos, desde Egipto al Magreb; por ello se ha avanzado que es más que probable que la parte que trata sobre todo el África septentrional de la obra homónima de al-Bakrī fuera copiada o extractada de la obra de al-Warrāq, sin que al-Bakrī lo reconocerá por escrito. Esto es muy probable, dado que al-Bakrī no llegó a viajar nunca por el Norte de África.

Por petición de al-Hakam II elaborará otras obras históricas y geográficas, especialmente centradas en temas relativos al Norte de África. ${ }^{11}$ No ha pervivido ninguna de ellas, salvo por lo que copiaron al-Bakrī, Ibn Ḥayyān e Ibn 'Iḍārī.

§ 7). Kitāb șūrat al-arḍ 'Tratado sobre la descripción de la tierra' de Muhammad Ibn Hawqal (m. desp. 378/ 988) (Van Arendonk EI 1934a; Miquel EI ${ }^{2}$ 1971; Ibn Hawqal De Goeje 1873; Kramers 1938; Ouseley 180o; Kramers y Wiet 1964). Esta obra también ha sido conocida como Kitāb al-masālik wa-l-mamālik, y con este título se editó su primera traducción inglesa en 1800 (Ibn Hawqal Ouseley).

Originario de Nașībīn (Alta Mesopotamia/al-Ŷazīra), debió pasar en esta región su infancia y adolescencia, comenta que deja Bagdad en ramadān 331/mayo 943 con la finalidad de conocer otras gentes y pueblos y hacer negocios comerciales. Con este motivo conocerá todo el mundo islámico, de este a oeste, ${ }^{12}$ motivo que

"Se menciona un Kitāb Ifrīqiya wa-mamāliki-ha, y al-Ḍabbī escribió que fueron "numerosas obras sobre la historia de los soberanos de Ifrīqiya, de sus guerras y de quienes se sublevaron contra ellos en Tāhart, Orán, Tanas, Siŷilmāsa, Nakūr y al-Bașra (del Magreb)». Informa Ibn Ḥazm en su Ŷamhara que era versado en genealogías, particularmente de los beréberes (apud. Guilliot $E I^{2}: 166$ ).

${ }_{12}$ De los viajes que emprende este comerciante y geógrafo en ramaḍān 331/mayo 943 pueden reconstruirse - al menos esquemáticamente-, en base a los datos dispersos en su obra: Norte de África, al-Andalus y los confines meridionales del Sáhara (336-340/947-951), Egipto y las regiones septentrionales del Islam: Armenia y Ādِarbaŷān (hacia 344/955), al-Ŷazīra, 'Irāq, Jūzistān y Fārs (3508/9619), Kwarizm y Transjoxania (hacia 358/969, finalmente Sicilia (362/973), tras lo que se le pierde su 
hizo afirmar a R. Dozy que fue un espía al servicio de los fatimíes. En estos viajes se encontró con al-Ișțajrī — probablemente sobre el 340/951·2 — y, a petición suya, revisó su obra y hará mejoras en alguno de sus mapas. Sin embargo, él decidirá reescribirla toda por completo y hacer una nueva versión a su nombre, con el mismo título de Al-Masālik wa-l-mamālik (Van Arendonk EI 1934a: 383). Esta obra fue corregida en varias redacciones sucesivas: La primera está dedicada al hamdān̄̄ Sayf al-Dawla, y habría sido por ello, anterior al 356/967, fecha de la muerte de este príncipe; la segunda, llena de prevenciones contra esta dinastía, está dedicada a un personaje no identificado, quien debió haber vivido hacia 367/977; la puesta en limpio definitiva de la obra debió ser realizada hacia el 378/988 (Miquel $E I^{2}$ 1971: 810). No conocemos la fecha de su muerte, pero indudablemente debió ser posterior a esta data.

§ 8). Kitāb al-'Azīż̄, también conocido por su otro título de Kitāb al-masālikwa-lmamālik, de al-Muhallabī (m. 380/99o) (Pellat EI² 1993; Roldán y Valencia 1988:13).Es un geógrafo del que solo se conoce la fecha de su muerte, y que escribió un tratado, hoy perdido, dedicado al califa fāțimī al-'Azīz bi-llāh (gobierna de 365-386/975-996), de ahí su título de Kitāb al-'Azīzī 'Tratado dedicado a al-'Azīz'. Su segundo título indica la voluntad de emparentarse con este tipo de obras de carácter geográfico.

Aunque no haya perdurado, podemos tener una idea de su contenido por los muchos autores posteriores que copiaron fragmentos (generalmente breves) de ella. ${ }^{13}$ Al igual que este tipo de obras geográficas incluye indicaciones sobre los itinerarios y las distancias entre poblaciones, y de las ciudades que describe con mayor o menor detalle recoge las coordenadas, historia y apuntes sobre su población, economía y sobre su aspecto y apariencia.

§ 9). Kitāb al-masālik wa-l-mamālik de Abū 'Ubayd al-Bakrī (432-487/1040-1094) (GAL I: 627-8, S I: 875-6; Al-Bakrī 1992; Cour EI; Lévi-Provençal $E I^{2}$; Lirola BA 2012), obra que no se ha conservado completa en ninguno de los manuscritos conservados y hasta hace no mucho no contábamos con una edición unitaria de los pocos fragmentos dispersos que han perdurado de ella. Al-Bakrī la está escribiendo en el 46o/1068, posiblemente en la taifa de Almería, en la corte de al-Mu'tașim.

Lévi-Provençal resume su estructura:

... siguiendo la norma de los geógrafos de su época y del siglo precedente, Abū 'Ubayd al-Bakrī ha querido, ante todo, como lo indica el título de su obra (descripción "de los reinos y los itinerarios") darle la forma de un rutero, contemplando a la vez la evaluación de las distancias entre cada población, o cada final de etapa. Había podido resultar una seca enumeración, sin duda interesante, pero bastante esquelética, si el autor no hubiera puesto su marca personal y

pista. Visita al-Andalus dos veces, una a comienzos el año 337 (11 de julio-9 agosto de 948) en época de 'Abd al-Raḥmān III, y luego una segunda vez en los años 363-4/974-5, en época de Almanzor.

13 C. Pellat enumera autores que copian de esta obra, tales como: Yāqūt al-Hamawī (57 citas, siendo la fuente esencial de sus datos sobre el Bilād al-Sūdān), Abū l-Fidā' (135 citas) y al-Qalqašandī (69 citas) (Pellat $E I^{2}$ 1993: 36o). 
escogido con buen criterio de entre la masa de informaciones que había sido capaz de reunir. Pues estas informaciones no son solo geográficas: ellas muestran en gran medida la historia política y social, y hasta la etnográfica, y esto es lo que confiere a los Masālik de al-Bakrī, al menos en lo que concierne al Occidente, un valor inapreciable $\left(E I^{2}: 161\right)$.

Comienza el tratado hablando de la extensión del mundo y de su creación, refiriendo historias de los profetas, creencias religiosas de los antiguos árabes y descripción de algunos edificios religiosos de pueblos diversos. La parte geográfica se inicia con la enunciación y detalles de río, luego de mares e islas. Sigue con la descripción de las tierras conocidas, partiendo desde la India, China en dirección al Magreb y Occidente. En los fragmentos conservados hallamos descripciones de los territorios islámicos y del Extremo Oriente (de los que se tiene datos desde antiguo). Para cada territorio se sigue un programa similar: introducción histórica, descripción general del territorio, habitantes, productos y descripción de las rutas. La última parte de la obra -tal y como se conserva- describe el continente europeo en su parte Ocidental; en ella es donde incluye una descripción general de al-Andalus y de algunas de sus ciudades, aunque en total se conservaron pocas páginas (Lirola BA 2012:157-8) Dos fuentes esenciales que utiliza profusamente para su composición ( sin citarlas, la mayor parte de las veces) son las obras de al-Warrāq y la de al-'Udrī.

Está claro que se trata de un eco tardío elaborado en al-Andalus, de la estructura del rutero enriquecido con informaciones históricas. Su composición, ya un siglo posterior a sus precedentes busca completarse con todo tipo de informaciones de carácter geográfico, etnográfico y económico, sin faltar también algunos relatos de 'ầ̄'ib.

§ 10). Kitāb tarșī al-ajbār wa-tanwī' al-ātāàr wa-l-bustān fì garāìb al-buldān wal-masālik ilà ŷamì al-mamālik, citado posteriormente como Niz̄ām al-marŷāan fì l-masālikwa-l-mamālik por otros geógrafos y compiladores, ${ }^{14}$ de Ahmad al-'Uḍrī Ibn al-Dalā'ī (393-478/1003-1085), obra acabada de componer en el 472/1079·8 $\mathrm{O}^{15}$ (Al'Ud_rī 1965; Molina $E I^{2}$; Lirola $B A$ 2012; Roldán y Valencia 1988: 14-8). Tradicionista y ulema que nació en Dalías y luego creció en Almería. Ante la turbulencia de la fitna, su padre decidió que viajaran a Oriente unos cuantos de la familia en 407/1016•7. Abū 'Ubayd contaba con 13 años. Durante los ocho años que estuvieron allí se formó

14 Así lo citan al-Idrīsī, Yāqūt al-Ḥamawī y al-Ḥimyarī. Según É. Lévi-Provençal su obra se habría titulado Niz̄ām al-marŷān fı mamālik wa-l-masālik (al-Ḥimyarī Lévi-Provençal: XXIV). Según afirma este investigador, de ella sacó amplio provecho su contemporáneo y discípulo, Abū 'Ubayd al-Bakrī, y de ella provienen igualmente las indicaciones que al-Qazwīnī escribió sobre al-Andalus.

15 Según el estudio de L. Molina, esta obra tuvo dos redacciones: "entre el 459 y el 468 (1066-76) redacta su primera versión; en el $472(1079-80)$ vuelve sobre el primitivo manuscrito y añade varias noticias históricas; finalmente entre ese año y el de su muerte $(478=1085)$ da la forma definitiva a su obra, que servirá de fuente a al-Qazwīnī, al-Ḥimyarī y al compilador del Dikr [bilād al-Andalus]» (L. Molina 1982: 260). 
con los más reputados sabios. En 416/1025.5 vuelve a al-Andalus, asentándose en Almería, y dedicándose allí a la docencia de las materias religiosas aprendidas en Oriente, hasta su muerte en la misma ciudad en 478/1085.

Hay noticia de otras obras suyas, hoy perdidas, pero es conocido sobre todo por esta obra geográfica e histórica. A. Carmona afirma del título de esta obra: "Peculiar y compleja disposición de las rimas tiene este largo título de al-'Udīī (s. XI), cuya primera parte no responde, además, a la consagrada fórmula de una única y concisa expresión (1987-89: 183)", luego amplía su análisis:

Este título encierra en realidad tres, cada uno de los cuales está además estructurado a partir de un recurso estilístico y gramatical diferente. [...]. Y es precisamente la disposición de las rimas la que me ha dado la llave para desenmarañar la aparente complejidad de lo que creíamos un título único aunque notablemente largo.

Veamos: tarșī al-ajbār wa-tanwī al-ātār ("Taracea de noticias y clasificación de tradiciones") indica que estamos ante un libro de historia, que, como sabemos, contiene valiosas informaciones sobre al-Andalus; al-bustān fì garā'ib al-buldān ("El jardín, libro que trata de las curiosidades de los países") alude a que también es una geografía fantástica, una enciclopedia de hechos insólitos; al-masālik ilà ŷamı̄ al-mamālik ("Los caminos que conducen a todos los reinos") señala que es igualmente un libro de itinerarios y de geografía en general (física, humana y política) (Carmona 2000: 89-9o).

Respecto a la estructura de la obra, la parte que se ha perdurado se inicia con unos 6 folios casi ilegibles que tratan parece ser que de Egipto (3), Siria (2) e Irán $(1)^{16}$ y luego el resto de las hojas sueltas del manuscrito tratan sobre al-Andalus. Esta parte concreta se ha dividido dedicando un capítulo a cada kūra -cora o 'provincia'-, comenzando por la Cora de Tudmīr; le sigue la Cora de Valencia; Cora de Zaragoza (el capítulo más extenso); Huesca y sus dependencias, con noticias de algazúas de Almanzor; Cora de Elvira (incompleta en su inicio); Cora de Sevilla; Niebla (incompleta al final); Cora de Sidonia (incompleta en principio y final); de Algeciras (incompleta al final); Córdoba (incompleta en principio y final), y finalmente acaba con una casida a 'Abd al-Raḥmān III al-Nāșir. ${ }^{17}$ Lo particular de esta obra, en lo cual ya se nota que es tardía, estriba en que no hay una simple adición de noticias a la descripción de un itinerario, sino que hay una perfecta estructuración de los datos expuestos: con una primera parte del capítulo dedicado generalmente a datos geográficos (descripción de ríos e hitos en la de geografía física de la provincia, itinerarios principales, divisiones administrativas, fiscales y partidas agrícolas de cada zona de la provincia, para acabar con la descripción de

16 Éstas no fueron incluidas en la edición de al-Ahwānī (Al-'Uḍrī), que solo recogió los restos referidos a al-Andalus, como su título indica: Nuṣuṣs 'an al-Andalus ...

${ }_{17}$ Que el editor al-Ahwānī publicó en este lugar (Al-'Uḍīi: 128), aunque debería haberse colocado al final de la Cora de Tudmīr. 
las principales ciudades, monumentos, hechos notables que se relacionan con ellas, con muchas leyendas -'aŷā'ib- que se les asocian, etc.); sigue una segunda parte en que se recogen los datos históricos de cada cora, ordenados cronológicamente (noticias desde la conquista, época emiral, personalidades notables y hechos o batallas de relevancia en que participaron, etc.). Hay que resaltar que, aunque acabada en el año 472/1079/80, en plena época de los reinos de taifas, al-'Uḍrī nos transmite la imagen fija de la división administrativa última del califato omeya, o sea, la descripción del al-Andalus omeya en su máximo esplendor califal, unos 8 o años antes del momento en que escribe. Como tal, el almeriense habría de ser añadido a la nómina de los "nostálgicos del califato".

§ 11). Informa Carl Brockelmann (GAL S I: 877) que el gran geógrafo al-Šarîf al-Idrīsī (ha. 493-571/ha. 1099-1175·6) (Seybold $E I^{\prime}$; Oman $E I^{2}$; Lirola $B A$ 2009; Nef 2010) escribió una segunda obra titulada Rawd al-uns wa-nuzhat an-nafs 'Jardín de la amistad y deleite del alma', también conocida por su otro título de Kitāb almasālik wa-l-mamālik'18 'Tratado sobre los itinerarios y los reinos' obra dedicada al rey siciliano Guillermo I (gobierna entre 1154-1166), monarca sucesor de Roger II y también mecenas suyo. Señala el erudito alemán que se conserva un compendio de esta obra conocido por su título de Kitāb [Uns] al-muhaŷ wa-rawd al-furây '[Solaz de] Corazones y prados de contemplación', obra que incluye cartografía aneja. ${ }^{19}$ Hemos añadido los corchetes para indicar el título completo con que es conocida en la actualidad y con el cual ha sido editada esta obra (GAL I: 477, S I: 877, al-Idrīsī 1984; Oman $E I^{2}$ : 1059).

Hoy tenemos más datos sobre este tema complejo e irresoluto. F. Sezgin ha afirmado en la edición del "pequeño Idrīs̄̄"20 que éste fue escrito en Sicilia probablemente hacia el final de la vida del autor para el emperador Guillermo I (m. 1166). Se ha venido estimando que el año 548/1154 (que desde hace tiempo se consideró como el año en que completó su Nuzha) fuera el del inicio del trabajo de redacción de esta segunda obra (Oman $\left.E I^{2}: 105^{8}\right)$. Esto parece poco probable, dado que por esta data no había culminado su primer trabajo.

'Imād al-Dīn al-Ișfahānī en su antología poética (Kitāb al-agānī), al citar su otra obra de farmacología, menciona el Rawd, citando como fuente a un poeta árabe de

${ }_{18}$ C. F. Seybold copia este mismo argumento, pero afirma que el título alternativo de esta segunda obra idrīsī fue Kitāb l-mamālik (wal-masālik) (EIı: 451), afirmando que ésta solo se ha preservado en el manuscrito n. 688 de la Biblioteca Ḥakīm Oglū 'Alī Paša de Estambul.

19 C. Brockelmann data este Al-Muhaŷ wa-rawḍ al-furaŷ en de 588/1192, según el manuscrito de la biblioteca Ḥekim Oglu (n. 688). Esto hoy sabemos que se trata de un error de datación, puesto que alIdrīsī habría muerto en $571 / 1175 \cdot 6$.

${ }^{20}$ Utiliza la denominación que diera a esta obra K. Miller. F. Sezgin aclara que en su edición facsímil reproduce las dos copias de los manuscritos de Istambul a causa de sus variantes: Hekimoğlu MS 688 (162 folios, s. XIV J.C) y Hasan Hüsnü MS 1289 (120 folios, copiado posiblemente en 1679 J.C.), ambos en la Süleymaniye Library, de Istambul. El libro es la reproducción fotomecánica de los dos manuscritos precitados (por lo que no es una edición árabe al uso), con una breve introducción en inglés y en árabe (Al-Idrīsī). 
Sicilia, Ibn Bišrūn (m. antes 561/1166) quien, hablando de al-Idrīsī le atribuye dos obras, una geográfica y la otra literaria. ${ }^{21}$ Insiste G. Oman (1990: 33) en que no se comprende, pues, por qué en una antología poética se haya querido insertar una obra geográfica, sobre todo cuando el mismo nombre de Raw d al-uns indica más un título poético y no un contenido geográfico; esto, en su opinión deja aún abierto el debate en cuanto a las características de la obra titulada Rawd al-uns (que de este modo no habría sido una obra geográfica). Ahora bien, una vez editados los dos -bien diferentes- manuscritos de la titulada Uns al-muhaŷ wa-rawd al-furaŷ es evidente que se trata de un compendio geográfico, muy similar a su gran Nuzhat al-muštāq, aunque diferente en el texto y en la cartografía. En este mismo sentido habría de interpretarse la mención de Abū l-Fidā', quien en su Taqwīm al-buldān alude a una obra que denomina Kitāb al-Šarīf al-Idrīsīfì l-mamālik wa-l-masālik.

A. Nef ha aportado nuevos datos al debate respecto a la fecha de composición de la Nuzhat al-muštāq: apunta la fecha de 548/1154 no como la de la conclusión de la obra, sino como la del inicio, y la del Uns al-muhây, según una de las copias manuscritas, parece haber sido concluido en 1192, lo que indicaría que al-Idrīsī se habría quedado en Sicilia trabajando tras la muerte de Roger II, lo cual coincide con algunas de las pocas noticias que poseemos sobre él. Para la fecha de su muerte, afirma que no sabe de dónde se ha extendido la fecha del 1164.5 , y propone la de 571/1175.6 (Nef 2010: 63-64). J. H. Kramers pensaba que el manuscrito de Estambul de esta obra (que K. Miller bautizó como "Pequeño Idrisi") era un extracto del "Gran Idrisi” realizado en 588/1192 y rehecho un siglo más tarde, ya que contiene una descripción sumaria de un octavo clima al sur del Ecuador y una referencia al autor Ibn Sa'īd, quien vivió hacia 1270 (Oman $\left.E I^{2}: 105^{8-9}\right)$.

§ 12). Masālik al-abșār fi mamālik al-amșār, que también encontramos en algunos otros manuscritos con la variante menor del título de Masālik al-abșār fì ajbār mulūk al-amșār, obra de Ibn Faḍl Allāh al-'Umarī (700-749/1301-1349) (GAL S I: 218, S II: 175; Al-'Umarī; Salibi $E I^{2}$ ), una obra ya muy tardía, en comparación con las citadas. Los Masālik al-abṣār fı́mamālik al-amṣār es una obra enciclopédica que versa sobre numerosos temas (literatura, historia, geografía, religión y derecho, política y administración). Tanto ésta, como su otra obra (Ta'rîf bi-l-muștalaḥ alšarīf), ${ }^{22}$ son referencia obligada en lo que concierne a la administración durante el periodo mameluco, y luego fueron imitadas por otros autores, como al-Qalqašandī (Ṣubḥal-a šà). Los Masālik ya supone el salto de una obra geográfica "enriquecida" a

${ }^{21}$ El qui pro quo nace de la lectura de una palabra árabe que en singular significa "el mismo argumento" y en plural "temas poéticos" y que puede escribirse igual en singular y en plural. A caballo entre estas dos interpretaciones, escribió Ibn Bišrūn: “... eccelente descrittore di temi poetici, che conosceva bene. Elevava costruzioni incantiatrici soprattutto quando ricamaba intorno alla composizione, poemi a doppia rima e arricchiva i suoi bei versi» (Oman $E I^{2}$ 1990: 33).

${ }^{22}$ El Ta'rî́f bi-l-muștalah al-šarî́f es un manual de la administración que describe la organización del imperio mameluco en sus diversas provincias y cómo se coordina la administración de la cancillería central de El Cairo con otras administraciones centrales y provinciales (Salibi $E I^{2}: 781$ ). 
un tipo de tratado puramente enciclopédico, en el cual lo geográfico ya ha quedado diluido en una multitud de saberes diversos, sin que lo geográfico tampoco sirva como eje o criterio para la ordenación del contenido.

A. Carmona califica este título como "feliz enriquecimiento de la repetida fórmula: K. al-masalik wa-l-mamalik (1987-89: 183-4)" y lo traduce como 'Los Caminos de la vista: libro acerca de los diversos reinos', mientras que en la segunda variante del título éste será 'Los Caminos de la vista: historias acerca de los diversos reyes'; en ambos casos se obvia la traducción de amșār , 'de las metrópolis, comarcas', porque 'reyes de las comarcas' no supone precisión a lo anterior.

§ 13). Aqwām al-masālik fi márifat aḥwāl al-mamālik 'El más apropiado de los caminos, [tratado] para conocer las condiciones de los reinos', de Jayr ad-Dìn alTūnisī (1822-189o) (GAL S II: 887). Obra publicada por primera vez en 1868. El general Jayr ad-Dīn, su autor, fue un mameluco circasiano, ministro de Bey de Túnez en la corte del Bardo de 1873 a 1877, antes de ser llamado a Constantinopla -la capital del imperio- durante unos meses a finales de 1878. La obra en sí es bastante corta (75 páginas), y en ella Jayr ad-Dīn no presenta un proyecto específico de reforma del estado. Está encabezada por una larga introducción que arroja luz y pistas, generalmente veladas, sobre un gobierno tunecino que va camino a la bancarrota. Su estilo se queda en las generalidades, pero con sus numerosas referencias va exponiendo su particular modelo de "buen gobierno" (que recuerda al ilustrado siglo XVIII).

§ 14). En el GAL de C. Brockelmann hallamos citados dos manuscritos de autores que no hemos podido identificar, cuyos títulos pueden emparentarse con esta familia: Uno primero es Masālik al-abșār fi mamālik al-amșār wa-'aŷāib al-ajbār ilj (GAL S II: 1026. ${ }_{6}$ ) 'Los Caminos de la vista, libro acerca de los diversos reinos y maravillas de las historias, etc.', de Muḥammad Ṣāliḥ Ibn Ḥasan al-'Iṣāmī, manuscrito que se encuentra en la Biblioteca Central de El Cairo ${ }^{23}$.

Desconocemos el carácter y la temática de esta obra, pero su autor le puso un título idéntico al de la obra de al-'Umarī, aunque más largo, ya que se ha añadido una tercera parte de significado al mismo, referida a las historias maravillosas. La abreviatura ilj (ilà ajiri-hi), indica que el título era más largo, pero que el propio copista lo abrevió. Es obra por tanto posterior al s. VIII/XIV.

§ 15). La segunda obra que recoge el $G A L$ en su índice de títulos de obras citadas (S III: 789-1166) es el manuscrito ${ }^{24}$ titulado Al-Masālikfíl-mamālikfi-l-gubār (GAL S II: 1023. $_{66}$; ) que puede interpretarse como 'Los caminos, [tratado] sobre los reinos de lo desconocido', cuyo autor es Abū Manșūr Muhammad Ibn Mukarram Ibn Sa'bān al-Kirmānī (m. 975/1567.8 o en $983 / 1575 \cdot 6)^{25}$. Esta obra ha sido objeto de una tesis

23 Le asigna la signatura Kairo III, $35^{2}$.

24 Según C.Brockelmann responde a la signatura de la Biblioteca Daḥdāh, n. 16.

25 Los historiadores discrepan sobre la muerte de al-Kirmānī: Ḥaŷȳì Jalīfa afirma que fue en 975/1567·8 (siguiendo a Jațīb al-Bagdādī y ‘Umar Kaḥhāāa), mientras que al-Zarkālī afirmó que sobre el $983 / 1575 \cdot 6$. 
doctoral ${ }^{26}$ y de una posterior publicación. Su editor, Sa'ūd al-Šuraym, ha concluido que esta obra se titula Al-Masālikfì l-manāsik 'Los caminos, [tratado acerca] de los ritos [del haŷŷ]', siendo realmente una guía que recoge todos los rituales que han de seguir los peregrinos que hacen el ḥâŷy a La Meca (al-Kirmānī).

El manuscrito presenta un título similar a $K M M$, habiéndose normalizado $f i$ l-manāsik como fì l-mamālik, para así ahormarlo como el conocido rótulo de las referidas obras geográficas.

\section{AL-MASĀLIK WA-L-MAMĀLIK: UNA ESTRUCTURA EXPOSITIVA HEREDADA DE LOS ITINERARIA ROMANOS CONVERTIDA EN GEOGRAFÍA DESCRIPTIVA}

\subsection{La clasificación de la escuela francesa}

Después de hacer un análisis de la historiografía referente a estas obras hemos apreciado que ha habido una clara evolución en la precepción y en la clasificación de los tratados titulados como KMM, desde mediados del s. XIX a mediados del s. XX. Carl Brokelmann ya los clasificó en su GAL en los subepígrafes dedicados a la geografía, describiéndolos como "itinerarios". En esa misma línea a mediados del s. XX, Évariste Lévi-Provençal en la biografía que dedica a al-Bakrī en la $E I^{2}$ dice que su $K M M$ tiene la "forma de un rutero", aportando valiosas notas sobre su estructura (que hemos recogido en el § 9) en cuanto a compendio de itinerarios y caminos, al que se has añadido historias de las tribus locales del Magreb (con seguridad copiada de la obra homónima de al-Warrāq) y otras referencias de geografía descriptiva (económica, física, humana).

Ahora bien, Blachére en su primera edición de sus Extraits, de 1938, y en la segunda con Darmaun, en 1952 (111-5), ya hacen una clara y cerrada presentación de estas obras como género de "Los itinerarios", proponiéndolo como una reacción a la "geografía de gabinete", estos autores "se ponen ellos también a recorrer el mundo" (111), afirmando que todos sus autores son orientales (113). Así, incluye en este género a al-Ya'qūbī, al-Ișțajnī, al-Baljī, Ibn Ḥawqal y al-Muqaddasī, incluyendo también a alBakrī y al-Idrīsī, pero sin aclarar por qué han de incluirse dentro del género. Ellos ponen el relieve en la oposición de la "geografía sedentaria" -representada por Ibn Jurradādbih- y la "geografía de los viajeros", escrita a partir de su experiencia personal del viaje, con la finalidad de elaborar otro tipo de obras:

II est aisé de voir tout ce que le genre al-masálik wa l-mamálik doit aux compendia á l'usage des Secrétaires. A première vue même, on serait tenté de ne voir dans les ouvrages qui le représentent qu'une imitation servile de celui d'Ibn Khordádhbeh. Comme dans celui-ci, en effet, la nomenclature géographique y occupe une place importante et nous venons de voir que le mode d'exposition par itinéraires y a été conservé. II faut pourtant noter que le genre al-masálik wa l-mamálik a une originalité propre. II est bien vrai qu'il a encore maintes attaches

${ }^{26}$ En la Kullīyat al-Šarī‘a de la Ŷāmi‘at Umm al-Qurà, de La Meca, año 1424 H./2003 eC. 
avec sa souche originelle, mais il n'est pas seulement une sèche énumération de noms de reliais ou d'accidents géographiques. Les auteurs dont nous venons de parler sont des descriptifs. Toute leur attention porte sur la notation des aspects généraux d`un pays, la fixation des détails relatifs á chaque lieu, sur la vie des régions géographiques, dans le passé, sur leur vie présente. Sans doute tout cela est consigné de façon forte monotone, en général. Il n'importe, c'est suffisant pour constituer une différence marquée avec les compendia destinés aux fonctionnaires de l'administration, dont les auteurs ne semblent jamais avoir voulu être des écrivains, au sens commun du terme. En un mot, le genre est bien la continuation de celui créé par Ibn Khordádhbeh, mais il en est l'épanouissement (Blachère y Darmaun 1957: 1155).

En consecuencia, definen un género itinerario primero, el de estos geógrafos compiladores de gabinete, con el mencionado Ibn Jurradād bih a la cabeza, y lo diferencian de estos autores que escribieron unas obras itinerarias "enriquecidas" con datos geográficos, históricos y etnológicos. En línea con lo expuesto por los dos investigadores franceses, André Miquel avanza en esta línea interpretativa y la llega a presentar como l'"Avènement d'une véritable géographie humaine", desarrollando largamente las ideas antes expuestas (Miquel 1967: 267-330)

Las opiniones de los referidos investigadores de la escuela francesa fueron asumidas y repetidas por otros posteriores. Pero solo la escuela anglosajona discrepará de esta presentación, aunque no de modo abierto, pero sí ofreciendo otro tipo de clasificación. De este modo Maqbul Ahmad en su artículo sobre "Djughrāfiyā" de la $E I^{2}$ ya adopta otro enfoque, calificando a estos autores como la "Escuela de al-Baljī", mientras que G. R. Tibbets estudió la transmisión de textos y de la cartografía de esta "escuela de al-Baljī, diferenciándolos del resto de la escuela iraquí de geógrafos (Tibbets 1992). Se puede afirmar que la consideración de su cartografía adjunta, además de los textos, hace que se modifique la percepción general de las obras por parte de estos investigadores anglosajones.

Con posterioridad, se sigue utilizando la denominación de "género de al-masālik wa-l-mamālik" de la escuela francesa, pero cada vez se utiliza más la denominación de "escuela de al-Baljī", o incluso "escuela del Atlas del islam", si se habla de mapas.

\subsection{Un planteamiento alternativo en un origen romano}

El que haya práctica unanimidad en tres aspectos puede ser un buen punto de partida: 1. En las obras de $K M M$ se percibía que tenían en común su estructura como ruteros. 2. Con el tiempo, estos ruteros se identificaron en seguida con esta feliz etiqueta, de modo que el autor que decidía incluir en su obra una importante carga de descripción de itinerarios y de lugares no dudaba en titularla como KMM. 3. Esta característica estructura de ruteros -o itinerarios- se va complicando y enriqueciendo con el tiempo, en igual medida que el propio título también lo hará. 
Hay que resaltar que cualquier análisis que hagamos a la producción cultural escrita en árabe normalmente suele tener en consideración y seguir el criterio que la propia historia de la literatura o la historiografía árabes han consignado para esa obra, de modo que los géneros o los temas literarios son propios y beben de su tradición. Raramente se mira hacia otras literaturas o se utiliza la metodología de la literatura comparada. Saliéndose de esta inercia, José Ramírez del Río viene a apuntar y a demostrar hasta qué punto el género grecolatino del catálogo (Pinakés o De viris illustribus), del acopio de noticias biográficas sobre personalidades del pasado, tuvo un desarrollo en el período helenístico, y cómo poniendo su forma al servicio del cristianismo, por ser conocido y divulgado en la Iglesia de Oriente Medio, al final esta Iglesia hará de puente hacia el que la literatura árabe conocerá como el género țabaqāt. ${ }^{27}$ Esto demuestra cómo puede hacerse una relación de filiación con los bizantinos, y su evolución en un mundo ya islámico, con una estructura y organización similar, pero con una finalidad diferenciada, hacia los diccionarios biográficos de hombres de religión (2016).

De idéntico modo, cuando leemos las descripciones itinerarias que hallamos en la obra de Ibn Jurradādbih o en el resto de los autores ya referidos, nos evoca y remite a los pocos ejemplos que han pervivido de itinerarios romanos. El único que ha pervivido completo es el Itinerario de Antonino (ha. 280), 28 que es un rutero en su misma esencia: en su forma textual el Itinerario de Antonino aparece como una simple enumeración de topónimos (con indicaciones direccionales) de las diversas

27 “Ṭabaqāt es la traducción árabe tanto de la palabra como del género Pinakés, recibido a través de la mediación de la Iglesia del Este, de la Iglesia nestoriana, que había utilizado dicho género tanto en su forma primitiva, legada de Calímaco y actualizada en el siglo VI por Hesiquio de Mileto, como en una forma híbrida, cercana a la hagiografía, que fue la característica propia de la historiografía, de la forma de afirmación de la comunidad nestoriana en el imperio sasánida primero y en el islámico después" (Ramírez del Río 2016: 140).

28 El Itinerarium Provinciarum Antonini Augusti también conocido como Vetera Romanorum Itineraria es un ejemplo del sistema romano de descripción utilitaria de las calzadas del imperio. La copia que se conserva es de tiempo de Diocleciano, más concretamente en torno a 29o, aunque aprovecha elementos un siglo más antiguos. Se ha pensado que es una compilación, una completa guía de las vías romanas y de sus diferentes etapas o mansiones destinada para el uso de caminantes. Pero las irregularidades de las etapas y los bruscos cambios de dirección, sin lógica ni utilidad aparente, en muchos de los caminos que se describen han intrigado a los estudiosos. Entre los que han buscado dar una respuesta a ello, a comienzos de siglo Denis van Berchem (1937) apunta dos conclusiones sobre el por qué fue escrito el Itinerario de Antonino: 1. La ruta central y más larga del itinerario se había puesto por escrito para organizar el viaje de Caracalla desde Roma hasta Egipto en 214 y 215. 2. Las demás hojas de la ruta recopiladas en el documento correspondían a trayectos que debían seguir ciertas unidades militares, la mayor parte de las veces para recaudar la annona, impuesto pagado en especie en las mansiones acondicionadas al efecto. En consecuencia, lo que determinaba el emplazamiento de cada mansio no era tanto la longitud de la etapa, como la existencia allí de una comunidad de contribuyentes. Las mansiones también habrían de poseer silos y graneros para su almacenamiento local. En cualquier caso, no sabemos si en origen se prescindió de cualquier tipo de cartografía, o esta se ha perdido (pensamos en un tipo de representación similar al de la Tabula Peutingeriana). Con posterioridad Gonzalo Arias (1987:487-8) en diversas publicaciones ha insistido y divulgado esta relación entre annona e Itinerario.

ISSN $1132-0265$

http://dx.doi.org/10.12795/PH.2017.i31.11

Philologia Hispalensis 31/2 (2017) 37-66 
mansiones en que se finaliza cada etapa del camino, junto con la anotación de las distancias entre cada ellas. Describe un total de 372 caminos del Imperio, los cuales suman casi 7000 millas; se trata de vías estatales, o primarias, faltando los caminos provinciales, y los vecinales o secundarios. Incluye además unos derroteros por el Mediterráneo. Este es el rutero por excelencia, el más conocido.

Hay quien piensa que fue elaborado como guía para uso de caminantes; así Roldán ha visto al Itinerario de Antonino como un ejemplo único conservado de una compilación o guía de las calzadas del Imperio Romano (Arias 1987: 487505; Franco 2005a), aunque es una compilación demasiado tardía, ${ }^{29}$ motivo que explicaría su escasa difusión y poca utilidad. En un sentido interpretativo opuesto, D. van Berchem defendió que se trata de un texto surgido de la prefectura encargada del cobro, almacenamiento y gestión de la anonna; ${ }^{30}$ El Itinerario de Antonino habría tenido por base una serie de edictos (conservados en los archivos imperiales) cuyo objeto habría sido el preparar expediciones de tropas encargadas especialmente de recaudar el impuesto de al annona. Como tal texto surgido de la prefectura de la anonna, tendría, por tanto, un fin restringido a los funcionarios de esa prefectura imperial. El que haya tenido tan restringida difusión parece abonar esta interpretación, aunque no lo confirma.

Escasos repertorios itinerarios más de época romana han perdurado. Como muestra estadística, J. M. Roldán Hervás compiló y estudió en 1975 los más importantes referidos al solar de Hispania romana. Entre ellos merece un lugar especial el tardío mapa de rutas que es la conocida como la Tabula Peutingeriana (ca. 330), 31 extraordinaria por ser un documento cartográfico único, sin otro

29 Señala Roldán que es el único ejemplo que ha pervivido, "si excluimos la llamada Tabula Peutingeriana, de un género que debió estar extraordinariamente extendido por su naturaleza técnica y práctica, pero que, precisamente, debido a esa naturaleza exclusivamente práctica, desapareció en el momento en que las condiciones geopolíticas lo hicieron inservible" (Roldán 1975: 19), esto es, con el resurgimientos de fronteras internas en el impero, consecuencia de los reinos independientes que surgieron a partir del s. IV.

30 En el Imperio Romano el ejército a través de las vías construidas al efecto procedía a la recaudación del impuesto de la annona, constituido por trigo, aceite, vino, cebada, centeno, carne, legumbres, etc., y esta annona estaba destinada a sufragar los gastos del ejército y las necesidades de la provincia. Los productos recaudados se almacenaban en graneros provinciales al efecto, en las mansiones; una mansio era una estación acondicionada para que en ella pernoctasen soldados y funcionarios que viajaban por cuenta del Estado, y con almacenes donde aprovisionarse ellos y sus tropas. A estos almacenes, silos o graneros llevaban las respectivas contribuciones (annonae) los propietarios de su entorno, o si se trataba de comunidades lejanas era el propio ejército quien acudía a por el impuesto (Franco 2008: 336). Ya apuntamos esta institución romana como el precedente directo de la estructura de los silos estatales (o alfolíes, al-hurī pl. al-ahrā') del al-Andalus omeya (Franco 2008: 334-340).

${ }^{31}$ La Tabula Peutingeriana es el itinerari picti más antiguo del mundo romano (Scheyb et alii 1824; Desjardins 1869-74; Miller 1887; Roldán 1975: 148-16o). Recibió su nombre de su propietario Conrado Celti Peutingero (Conradus Peutinger), economista, hombre literato y docto, nacido en 1465 en Augsburgo (Augustae Vindelicorum). Fue amigo del Maximiliano I y jurisconsulto de Carlos V. Murió en 1547 legando en su testamento esta Tabula Peutingeriana. Konrad Miller (1887), el más importante

ISSN $1132-0265$

http://dx.doi.org/10.12795/PH.2017.i31.11

Philologia Hispalensis 31/2 (2017) 37-66 
paralelo conocido (aunque sabemos que debieron existir) e itinerario a la vez. Otro documento literario, aunque tardío es el listado de topónimos del Ravennate (s. VII). ${ }^{32}$ Entre los documentos de la cultura material el más importante, sin duda son los Vasos de Vicarello (s. I), ${ }^{33}$ cuatro vasos con indicación del camino de Cádiz a Roma. Otros documentos diferentes a anotar son el Itinerarium maritimun, de algún

estudioso de la Tabula, llevó a cabo una reconstrucción pictórica de la parte perdida. En la actualidad puede consultarse en sus diversas copias, con estudios e historiografía en la web: https://www.hsaugsburg.de/ harsch/Chronologia/Lsposto3/Tabula/tab_intr.html [Consultado: 10/10/2017]. La Tabula Peutingeriana es un mapamundi que fue elaborado en algún momento de la Edad Media que no se ha podido precisar con exactitud (una copia data de ca. 1250). Su importancia radica en que el mapa parece ser una copia de un mapa romano anterior, probablemente del siglo IV de nuestra era. Es realmente un esquema que representa cartográficamente la más antigua compilación de itinerarios del mundo romano (Scheyb et alii 1824; Desjardins 1869-74; Miller 1887). El mapamundi abarcaba la zona comprendida entre la península Ibérica y la India. Era un rollo muy largo, teniendo una longitud de $683 \mathrm{~cm}$. por $34 \mathrm{~cm}$. de altura; su extremo final contenía la parte de Hispania y las islas británicas; ésta por ser la parte más externa, la que envolvía al resto del documento, al estar más expuesta al uso acabó por perderse. K. Miller parte de la base de que el autor de la Tabula se basó en el Mapamundi de Castorius que aparece constantemente citado en el llamado Anónimo de Rávena. Sin embargo, el Ravennate está lleno de fallos (confunde al Ptolomeo geógrafo con el rey egipcio) y no nos consta la existencia de ningún geógrafo ni cartógrafo llamado Castorius, de modo que la reconstrucción ofrece numerosos puntos oscuros que la hacen discutible. Se la acompaña y relaciona generalmente del Itinerarium Gaditanum, (ca. 330), que es oto modo de llamar a los Vasos de Vicarello (vide nota 33).

${ }^{32}$ El Anónimo de Rávena (o Ravennate) es un desconocido compilador de una Cosmographia, como él denomina a su obra (Schnetz 1940; Roldán 1975: 111-142), dividida por sus editores posteriormente en cinco libros. Con excepción del primero, los otros cuatro recogen una seca enumeración de unos 5300 topónimos, entre ellos 300 hidrónimos o nombres de ríos, y el resto, nombres de ciudades que, dentro de las diferentes regiones e islas, solo en parte se enumeran por provincias de u modo bastante irregular y desordenado. A pesar de su título, es en realidad un catálogo nominal de tipo cosmográfico que abarca todo el mundo conocido hasta entonces. Su autor afirma que escribe en la corte de Rávena, en una fecha que sabemos que es en el s. VII e.C. Su fuente de inspiración es un mapa de rutas, que suponemos del estilo de la Tabula Peutingeriana, aunque sabemos que no copia a ésta. Según Roldán, la fuente común al Ravennate y a la Tabula habría sido una mapa romano del s. III, que habría sido utilizado independientemente por sus dos autores. Quizás por ser su fuente un mapa y no un texto itinerario apenas ofrece datos de distancias entre los lugares enumerados (solo en el Libro V) limitándose en el resto a enumerar los puntos de los itinerarios sin indicación de las distancias. Los conceptos geográficos explicados en el Libro I están influidos por la patrística, de modo que la tierra está rodeada en toda su extensión por el océano y es iluminada completamente y al mismo tiempo por el sol, puesto que es una superficie plana; sigue una descripción de la tierra; el segundo libro comienza con Asia, luego África y Europa y termina con un periplo por el Mediterráneo y una relación de islas en los distintos mares y en el océano.

33 Los conocidos como Vasos de Vicarello o Vasos Apollinares, forman parte de un importante hallazgo arqueológico encontrado en $185^{2}$ en las termas de las Aquae Apollinares, establecimiento de baños termales aún en explotación en Bagni de Vicarello, junto al lago Bracciano, a 3o Km al $\mathrm{N}$ de Roma. Son un conjunto de cuatro recipientes cilíndricos de plata de alturas entre 9.5 y $15.3 \mathrm{~cm}$., en cuya superficie exterior están grabadas las etapas del camino que conducían de Cádiz a Roma. Se suponen que obra de orfebres gaditanos de tiempos de Augusto y estarían destinados al uso de los viajeros que se dirigieran a la capital del Imperio. En cada vaso el texto se distribuye en cuatro columnas. Se piensa que se trata de la ocasional ofrenda a Apolo de un peregrino gaditano de viaje a Roma, siendo la meta del viaje el propio establecimiento termal (Roldán 1975: 152-153; Arias 1987: 503516). Más recientemente, bajo el nombre de Itinerarium Gaditanum, (ca. 330) han sido publicadas

ISSN $1132-0265$

http://dx.doi.org/10.12795/PH.2017.i31.11

Philologia Hispalensis 31/2 (2017) 37-66 
modo, parte del I. de Antonino (Roldán 1975: 102-5), la tégula de Valencia (Roldán 1975: 161-2) o las tablas de barro de Astorga (Roldán 1975: 163-175), de relevancia itineraria e histórica menor (Arias 1987: 487-505; Franco-Sánchez 2005a).

Con ello encontramos que los ruteros o itinerarios sí que se hallan presentes en la vida cotidiana del imperio romano, especialmente a partir del Imperio. Los ejemplos conservados son tan singulares como tardíos, pero en su variedad hallamos desde un repertorio itinerario, un rutero puro como el Itinerario de Antonino, a un listado de topónimos de todo el orbe (Ravennate), hasta un mapamundi itinerario (Tabula Peutingeriana) y en varios ejemplos más se ven itinerarios parciales o regionales, en los más diversos soportes (desde vasos votivos, a tejas o cerámica), y desde el s. I al s. VII e.C.

Realmente un imperio no se erige ni se sostiene si no puede tener buenas comunicaciones, tanto terrestres, como en forma de circulación de correos, mercaderías y sobre todo soldados. Las vías romanas tenían la finalidad primordial de servir de arterias por las que se movía el ejército hasta el último rincón del mundo, y detrás de él fluía el comercio y la romanización. Como se ha enunciado, no solo elaboraron miliarios (grandes piedras talladas con información de las próximas mansiones y sus distancias, situadas a tramos regulares en las principales vías romanas), sino también anotaciones itinerarias en los más diversos soportes. Esta necesidad de recordar, de tener en cuenta, es el origen de compilaciones y en ella vemos el fundamento para la escritura del rutero. El más conocido e importante de todos, el Itinerario de Antonino, se nos muestra además como un documento oficial, como una compilación para el uso de funcionarios encargados del impuesto de la annona, de modo que en el mismo no podemos dejar de ver una relación genésica directa con los primeros tratados de $K M M$.

\section{GRUPOS DE ObRAS DENTRO DE LOS KMM}

La búsqueda de un título para una obra que anhela la fama no era tarea fácil para los autores árabes del período clásico, de ahí que fuera frecuente recurrir a la copia de las etiquetas famosas como recurso mnemotécnico que, unido al nombre del autor, constituyera un doblete garantía de éxito. Fueron numerosas las obras que llevaron este título de $K M M$, en su formulación inicial, o en sus derivadas, como consecuencia de la asociación de esta etiqueta de $K M M$ con libro, tratado de geografía, pero no de la geografía astronómica de herencia ptolemaica, sino de geografía descriptiva (tanto física, en la menor parte de los casos, como sobre todo de geografía humana).

Metodológicamente hemos dejado de lado las obras que no llevaban el título de Kitāb al-masālik wa-l-mamālik (aunque la literatura científica nos dijera que estaban emparentadas con ellas más o menos directamente) y hemos recogido y 
ordenado cronológicamente hasta 15 títulos de obras, junto con sus autores que nos informan de una serie de peculiaridades que vamos a desarrollar, puesto que de esta tabulación de información ya se pueden extraer unas primeras conclusiones respecto al por qué los diversos autores quisieron titular sus tratados como KMM.

1. En origen, estas obras fueron inicialmente compuestas por persas. Los más antiguos tratados son los de: al-Marwāzī, al-Sarajsī, Ibn Jurradādِbih, al-Ŷayhānī, alIștajrī e Ibn Ḥawqal. Como curiosidad, a partir del s.X, dejan de escribirse en Oriente y se escribirán en Occidente: el más antiguo tratado occidental así titulado es el de al-Warrāq (292-363/904-973), seguido por los de su contemporáneo al-Muhallabī (m. 38o/99o), Abū 'Ubayd al-Bakrī, al-'Ud dxī, al-Idrīsī, y volvemos a Oriente con al'Umarī. Solo con ello ya se podrían hacer dos grupos perfectamente diferenciados: en el espacio, y por su cronología.

2. Se han perdido las obras más antiguas, que informarían sobre el primer origen de este tipo de tratados (al-Marwazī, al-Sarajsī). Con ello, la más antigua conservada es la de Ibn Jurradādbih, quien, como jefe de correos y de espías en Ŷibāl, Bagdad y luego en Samarra elabora un manual para el uso de este tipo de funcionarios; en él encontramos los principales itinerarios orientales desarrollados en sus trazados, por regiones, a los que se añade información sobre las postas intermedias de los correos, divisiones provinciales y alguna que otra maravilla de algunas regiones. Está claro que es una relación de datos, que servirán para orientarse a un funcionario, pero no guiarán adecuadamente a un viajero.

Ibn Jurradādbih es el primer autor que tenemos constatado que elabora un 'Tratado sobre los caminos y los reinos', que deberemos entender como '[Compilación y guía de] los caminos [e itinerarios] y de todos los reinos [a los que conducen]'. Es esta una etiqueta eficaz y feliz, de modo que bien pronto fue conocida y se hizo más famosa que la limitada obra a la cual denominaba. La obra, compuesta en su versión definitiva en 272/885, tendrá un eco en un título idéntico, compuesto más o menos por estos mismos años por el primer al-Ŷayhanī (acabada después de 330/941·2), cuyo $K M M$ no ha perdurado. Debió de completar la obra homónima de Ibn Jurradādbih, con la cual se confunde en numerosas ocasiones los diversos autores.

La calidad de ambos autores, en una posición administrativa de privilegio para conseguir datos geográficos valiosos, e incluso en el caso de éste último, enviando cartas a sus corresponsales por todo el mundo, desde Bizancio a China, y recogiendo y clasificando los informes recibidos por escrito hablan claramente de su voluntad de elaborar un tratado valioso, expresando "que esto era para él el medio de llegar a conquistar estos países y conocer sus recursos".

2.1. El tratado Kitāb al-Jarāŷy, obra de Qudāma Ibn Ŷa‘far (m.320/932) en una parte del capítulo XI también incluye este tipo de información itineraria (Ibn Jurradādِbih $B G A$ VI; $184-229,144-172)$ a la que también se añaden itinerarios de postas. Pero realmente es una obra sobre el impuesto obligatorio en la que se incluye este tipo de información, luego no puede considerarse más que una utilización de la 
información ofrecida por los escritores antes enunciados, sin que su obra se halle relacionada con las de ellos.

2.2. A partir de al-Ișțajrī, deudo según sus propias palabras de la obra de al-Baljī (Kitāb șuwar al-aqālìm, también conocida por Taqwìm al-buldān), la cual copia e incluye en su $K M M$, con lo que la integra en una cadena, se enuncia la génesis de la que ha denominado "escuela de al-Baljī". Curiosamente su seguidor, Ibn Hawqal también dice mejorar la obra de al-Ișțajrī, pero no copia su rótulo, sino que lo cambia a Kitāb șūrat al-arḍ (aunque algunos autores se refieran a él por el otro de $K M M$ ). Sus obras ya son una clara evolución del simple itinerario. Se divide bien el globo por regiones y solo les interesa a este grupo la parte del islam, que es descrita en sus itinerarios, sus principales ciudades y distancias entre ellas, y luego se aportan datos económicos o circunstancias de relevancia o extraordinarias a ellas asociadas. Realmente serán ellos los que den una nueva forma a los secos itinerarios. Por un lado, sus obras son ricas en informaciones de muy diverso tipo, casi como si fueran informes elaborados para el poder, pero realmente los lectores serán esos persas cultos (šicies) a quienes se les presenta el mundo ante sus ojos. En segundo lugar se trata de una presentación muy parcial, religiosa e interesada, como desarrollaremos en un estudio posterior.

Esa voluntad de cambiar el título también la expresará su continuador, alMuqaddasī (Kitāb aḥsan at-taqāsìm fi ma'rifat al-aqālìm), quien ya elabora una obra no de ampliación del anterior, sino de complemento a sus predecesores.

2.3. Realmente a partir de estas dos líneas de presentación de los itinerarios asistiremos a un progresivo enriquecimiento del itinerario. Dicho de otro modo: la innovación ya no consistirá en encontrar una fórmula expositiva, que esto lo hizo la "escuela de al-Baljī", sino enriquecer los datos que cada obra pueda ofrecer. Como las obras van siendo progresivamente más tardías, este enriquecimiento será progresivo en el tiempo, pero curiosamente, se hará en el Occidente musulmán, más que en Oriente.

3. Al-Idrīsī en la parte publicada de su Uns al-muhaŷ nos ofrece el itinerario, el rutero que más tiene que ver con lo que debieron ser los itinerarios romanos. En la parte publicada sobre península Ibérica ofrece un sinfín de itinerarios en los que se indican las diversas etapas con indicación de la distancia entre ellas. Esta estructura recuerda al Itinerario de Antonino, incluso en las rutas marítimas que indica el Uns, que parecen un eco del Itrineratium maritimun (Roldán 1975: 102-5). Podría entenderse que con ello se cierra el círculo, se vuelven a los inicios, pero hay que anotar que al-Idrīsī trabaja en la corte sículonormanda de Palermo y que allí es más que probable que tuviera acceso a algún rutero romano, de modo que tenía un modelo que seguir. Así, cuando le fue solicitado un resumen caminero de su Nuzha, tuvo un modelo fácil para imitar. 


\section{REFERENCIAS BIBLIOGRÁFICAS}

Ambros, Arne A. (1990): "Beobachtungen zu Aufbau und Funktionen der gereimten Klassisch-arabischen Buchtitel, Wiener Zeitschrift für die Kunde des Morgenlandes 80, 13-57.

Arias Bonet, Gonzalo et alii (1987): Repertorio de Caminos de la Hispania Romana. Cádiz: G. Arias, 557 .

Berchem, Denis van (1937): "L’annone militaire dans l'Empire romain au IIIe siècle". Mémoires de la Société Nationale des Antiquaires de France 8o (8è. Série, t. X), 117-202. Trad. esp. en el volumen: Berchem, Denis van (2002): La annona y el Itinerario Antonino. Cortes de la Frontera (Málaga): Gonzalo Arias (Anexos de "El Miliario Extravagante", no 4), 3-30.

BLACHÈRE, Régis (1934): Extraits des principaux géographes arabes du Moyen Âge. BeyrouthAlger: Faculté des Lettres d'Alger (Col. Bibliotheca Arabica, n. VII) (392 pp.).

BLACHÈre, Régis/DARMAUn, Henri (1957 $2^{\mathrm{a}}$ ed.): Extraits des principaux géographes arabes $d u$ Moyen Âge. 2e éd. revue et corrigée par A. Darmaun. París: Librairie C. Klincksieck, 392.

CARMonA GonzÁLEZ, Alfonso (1987-88-89): "La estructura del título en los libros árabes medievales", Estudios Románicos. Homenaje al Profesor Luis Rubio 1, 4, 181-187.

CARMona GonzÁlez, Alfonso (2000): "Sobre la estructura convencional del título en los libros árabes", Al-Qanțara 21, 1, 85-95.

Connu, Georgette (1985): Atlas du Monde Arabo-Islamique a l'Époque Classique. IXe-Xe. Siècles. Leiden: E. J. Brill (213 pp.).

Franco-SÁnchez, Francisco (2005a): "La caminería en al-Andalus (ss. VIII-XV J.C.): Consideraciones metodológicas, históricas y administrativas para su estudio", TST. Transportes, Servicios y Telecomunicaciones 9, 34-64.

Franco-SÁnCHEZ, Francisco (2005b): "El occidente musulmán en los mapas del Mediterráneo de la "escuela de al-Baljî" (s. IV H./X J.C.)", en: Planet, Ana I./Ramos, Fernando (eds.): Relaciones hispano-marroquies: una vecindad en construcción. Madrid: Ediciones del Oriente y del Mediterráneo, 35-62.

Franco-SÁnchez, Francisco (2008): "The Andalusian Economy in Times of Almanzor. Administrative Theory and Economic reality trough Juridical and Geographic Sources", Imago Temporis. Medium Aevum 2, 83-112.

Kramers, J. H. (1932): “La question Balhīi-Ișțahrī-Ibn Ḥawḳal et l'Atlas de l'Islam”, Acta Orientalia 10, 9-30.

Miller, Konrad (1926-1927): Mappae Arabicae: Arabische Welt-und Länderkarten des 9-13. Jahrhunderts. Stuttgart, 6 vols. Reimpresión: Mappae Arabicae. Auszugsweise herausgeben und mit einem korrieerenden Index versehen von Heinz Gaube. Wiesbaden: ed. Ludwig Reichert (Beihefte zum Tübinger Atlas der Vorderer Orients. Reihe B. Geisteswissenschaften), 1986 (2 vols.). Reimpresión: Mappae Arabicae: Arabische Weltund Länderkarten des 9-13. Jahrhunderts. Frankfurt am Main: Institute for the History of Arabic-Islamic Science, 1994 (2 vols.).

MiQuel, André (1967): La géographie humaine du monde musulman jusqu'au milieu du ne. siècle. Géographie et géographie humaine dans la littérature arabe des origines à 1050. Tome 1. París-La Haya: Mouton \& École Pratique des Hautes Études (Col. Civilisations et Sociétés, n. 7) (426 pp.). 
MiQuel, André (1983): La géographie arabe après l'an mil. Volumen 29 de Settimane di Studio del Centro Italiano di Studi sull'Alto Medioevo. Spoletto: Centro Italiano di Studi sull'Alto Medioevo, 153-174.

MiQuel, André (1997): “La géographie”, en: Rashed, Roshdi (dir.): Histoire des sciences arabes. Technologie, alchimie et sciences de la vie. Vol. 3. Paris: Seuil, 55-71.

MiQuel, André (1975): La géographie humaine du monde musulman jusqu'au milieu du ne. siècle. Géographie arabe et représentation du monde: la terre et l'étranger. Tome 2. París-La Haya: ed. Mouton \& École Pratique des Hautes Études (Col. Civilisations et Sociétés, 37) (705 pp.).

MolinA, Luis (1982): “Las dos versiones de la "Geografía” de al-'Uḍr””, Al-Qanțara 3, 249-26o.

Mu'NIS, Husayn (1967 e.C./1386 H): Tārīj al-ŷugrāfı̀ya wa-l-ŷugrāfì̀ìn fì l-Andalus. Madrid: Instituto Egipcio de Estudios Islámicos (723 pp.).

NEF, Annliese (2010): "Al-Idrīsī: un complément d'enquête biographique", en: Bresc, Henri/ Tixier du Mesnil, Emmanuelle (dirs.): Géographes et voyageurs au Moyen Âge. Paris: Presses Universitaires de Paris Ouest, 53-66.

OMAN, Giovanni (1970): "A propos du second ouvrage géographique attribué au géographe arabe al-Idrīsī: Le «Rawd al-uns wa nuzhat al-nafs", Folia Orientalia 12, 187-193.

OMAN, Giovanni (1990): "Notizie bibliografiche sul geografo arabo al-Idrīsī (XII secolo) e sulle sue opere - IV", Studi Magrebini 22, 9-36.

PInTo, Karen C. (2016): Medieval Islamic Maps:An Exploration. Chicago/London: University of Chicago Press (406 pp.).

RAMírez DEL Río, José (2016): “Diccionarios bio-bibliográficos: de la antigüedad al mundo cristiano y al islámico", Hispania Sacra 137: 127-143.

Roldán CAStro, Fátima/VAlEnCIA, Rafael (1988): "El género "Al-Masālik wa-l-mamālik": su realización en los textos de al-'Udnī y al-Qazwīnī sobre el Occidente de al-Andalus", Philología Hispalensis 3, 7-25.

Roldán Hervás, José Manuel (1975): Itineraria Hispana. Fuentes antiguas para el estudio de las vías romanas en la Península Ibérica. Madrid: Universidad de Valladolid / Universidad de Granada (283 pp.).

Rosenthal, Franz (1943): Ahmad Ibn al-Tayyib al-Sarakhsī. New Haven, Conn.: American Oriental Society.

Rosenthal, Franz (ed.) (1992): Studies on Ibn Hurradādbih and al-Ğayhān̄̄, collected and reprinted. Frankfurt am Main: ed. Institute for the History of Arabic-Islamic Science (Col. Islamic Geography; vol. 39) (XXIII + $216+308$ pp.).

SEZGIN, Fuat (ed.) (1994): Studies on Ibn Hurradādbih (d. after 902) and al-Ğaihān̄̄ (d. after 978), collected and reprinted. Frankfurt am Main: Institute for the History of ArabicIslamic Science (Col. Islamic Geography; vol. 29) (XXIII + $216+308$ pp.).

TibBets, Gerald R. (1992): “The Balkhī School of Geographers", en Harley, J. B./Woodward, D. (eds.): The History of Cartography. Vol. 2. Book 1. Cartography in the Traditional Islamic and South Asian Societies. Chicago-Londres: The University of Chicago Press, 108-136. 


\section{Fuentes Documentales}

AL-BAKRī (1992): Kitāb al-masālik wa-l-mamālik. Nueva ed. ár. de la totalidad del texto conservado, en base a 10 manuscritos diversos de la obra: Van Leeuwen, Adrien P.; Ferré, André: Kitāb al-masālik wa-l-mamālik li-Abì 'Ubayd al-Bakrī. Qarțâŷ (Túnez): Dār al'Arabīya li-l-Kitāb / Bayt al-Ḥikma (2 vols.) Reimpresión (1992): [Beirut]: Dār al-Garb alIslāmī (2 vols.).

Al-Ḥimyanī (1938): Kitāb ar-Raw ḍ al-mițār fı jabar al-aqțār, ed. parc. ár., trad. fr. de los pasajes relativos a la península Ibérica y al Sudoeste francés: Lévi-Provençal, Évariste: $L a$ Péninsule Ibérique au Moyen Âge d'après le Kitāb ar-rawḍ al-mi'țār fì huabar al-akțāar d'Ibn 'Abd al-Mun'im al-Himyarī. Leiden: E. J. Brill (309 + 228 pp.).

IbN HAWQAL: Kitāa șūrat al-arḍ, o Kitāb al-masālik wa-l-mamālik. Primera ed. ár. Goeje, M. J. de (BGA, II): Bibliotheca Geographorum Arabicorum. Pars Secunda. Viae et Regna. Descriptio Ditionis Moslemicae, auctore Abu'l-Kásim Ibn Haukal. Lugduni Batavorum: E. J. Brill $(21+406$ pp.).

Iвn ḤAWQAL. Nueva ed. ár. Kramers, J. H. (1938): Opvs Geographicvm auctore Ibn Hawkal (Abū l-Kāsim Ibn Hawḳal al-Nașībù). Secundum textum et imagenes Codicis Constantinopolitani conservati in Bibliotheca antiqui Palatii $n^{\circ} .3346$ cui titulus est «Liber Imaginis Terrae». Leiden: E. J. Brill (2 vols.) (528 pp.).

IbN ḤAWQAL. Trad. ingl. Ouseley, William (180o): «Kitāb masālik wa-mamālik tașnîf Ibn Hawqal». The Oriental Geography of Ebn Haukal, an Arabian Traveller of the Tenth Century. Translated from a Manuscript in his own Possesion, collated with one preserved in the Library of Eton College. Londres: Oriental Press (327 pp.).

IbN HAWQAL. Trad. fr. Kramers, J. H./Wiet, G.(1964): Ibn Hawqal. Configuration de la Terre (Kitāb Șūrat al-Arọ), Beirut-París: Maisonneuve et Larose / Comission Internationale pour la Traduction des Chefs-Oeuvre (2 vols.) (551 pp.).

IbN JURRADĀD̄BIH (BGA, VI) (1889): Kitāb al-masālik wa-l-mamālik, ed. ár., trad. fr.: M. J. de Goeje: Kitâb al-Masâlik wa'l-Mamâlik (Liber Viarum et Regnorum) auctori Abu'l Kâsim Obaidalla ibn Abdallah Ibn Khordâdhbeh et excerpta e Kitâb al-Kharâdj auctori Kodâma ibn Djaffar, quae cum versione gallica edidit, indicibus et Glosario instruixit M. J. de Goeje. Leiden: E.J. Brill (Bibliotheca Geographorum Arabicorum. Pars Sexta) (307 pp.). Reedición (1967): Leiden: E. J. Brill. Reimpresión (1992): Fuat Sezgin: Ibn Khordadhbeh, Abu'l-Kasim Obaidallah: «Kitab al-Masalikwa'-Mamālik», auctore Ibn Khordādbeh Accedunt excerpta $e$ «Kitab al-Kharadj» auctore Kodama ibn Djafar. Frankfurt am Main: Institute for the History of Arabic-Islamic Science (Col. Islamic Geography; vol. 39) (XXIII + 216 + 308 pp.). Tras una introducción de XXIII pp., la obra de Ibn Jurradāḍbih se edita (pp. 2-183) y traduce (pp. 1-144) en primer lugar. En la segunda parte está el Kitāb al-jarāŷy de Qudāma Ibn Ŷafar (ed. ár. pp. 184-266; trad. fr., pp. 144-208). Reimpresión (2014): M. J. de Goeje: Ibn Khurrādadhbih's Kitāb al-Masālik wa'l-mamālik and part of the Kitāb al-kharāj by Qudāma ibn Ja'far. Leiden: E. J. Brill.

IbN JuRRADĀDַBih. Trad. fr. Barbier De Meynard, C. (1865): "Le Livre des Routes et des Provinces, par Ibn-Khordadbeh, publié, traduit et annoté”, Journal Asiatique $6^{\mathrm{a}}$ serie, 5 , 5-127, 227-296, 446-532.

AL-IDRĪsī (1984): Uns al-muhaŷ wa-raw ạ al-furaŷ reproducción de los dos mss. de la Süleymaniye Library de Istambul e introd. por: Sezgin, Fuat: Al-Idrīsī (d. ca.560/1165). Uns al-muhaj wa-rawd al-furaj. The Entertainment of Hearts, and Meadows of Contemplation. 
Frankfurt am Main: Institute for the History of Arabic-Islamic Science (Series C - 7) (570 pp.).

AL-IDRīsī. Ed. parc. ár., trad. esp. Mizal, Jassim Abid (1989): Al-Idrīsī. Los caminos de alAndalus en el siglo XII según Uns al-Muhaŷ wa-rawḍ al-furaŷ (Solaz de corazones y prados de contemplación). Madrid: CSIC (425 pp.).

AL-IșṬAJRĪ. Ed. ár. Goeje, M. J. de (BGA, I) (1870): Bibliotheca Geographorum Arabicorum. Pars Prima. Viae Regnorum. Descriptio Ditionis Moslemici auctore Abu Isháh a-Fárisí alIstakhrí. París: E. J. Brill (XI + 348 pp.). Reimpresión (1927/1967): Leiden: E. J. Brill (XI + 347 pp.).

AL-IșṬAJRĪ. Ed. ár. 'Abd Al-'Āl Al-Ḥīn̄̄, M. Ȳābir (1381/1961): Al-Iștajrī. Kitāb al-masālik wa-lmamālik. El Cairo: [s.d.].

Anónimo de Rávena. Ed. lat. Schnetz, Joseph (1940): Ravennatis Anonymi Cosmographia et Guidonis Geographica". Itineraria Romana. Vol. 2. Lipsiae (Leipzig): Teubner (X + 142 pp.).

JAYR AD-DīN. Ed. ár Al-Šanūfī, Al-Munșif (200o):Jayr ad-Dīn at-Tūnisī. Aqwām al-masālik fì ma'arifat aḥwāl al-mamālik. Túnez: Al-Maŷma' at-Tūnisī li-l-'Ulūm wa-l-Ādāb wa-l-Funūn Bayt al-Hikma (2 vols.).

Al-Kirmānī, Abū Manșūr Muḥammad Ibn Mukarram (2003): Al-Masālikfíal-manāsik. Ed. ár Al-Šuraym, Sa'ūd Ibn Ibrāhīm Ibn Muhammad: Al-Masālik fĩal-manāsik li-AbīManșūr Muḥammad Ibn Mukarram Ibn Ša'bān al-Kirmānī. Beirut: Šarika Dār al-Bašāir al-Islāmīya (2 vols.) (1298 pp.).

AL-MAs'ūDī: Kitāab at-tanbīh wa-l-išrāf. Ed. ár. De Goeje, M. J. (BGA, VIII) (1894): Bibliotheca Geographorum Arabicorum. Vol. 8. Kitâb at-tanbîh wa'l-ischrâf auctore al-Masûdî. Leiden: Brill. Reedición (1967): Leiden, ed. E. J. Brill.

AL-MuQAdDAsī [al-Maqdisī].Ed.ár. Goeje,M.J.de (BGA,III) (1877):Bibliotheca Geographorum Arabicorum. Pars Tertia. Descriptio Imperii Moslemici auctore Al-Mokaddasi. Leiden: E. J. Brill (7 + 499 pp.) Segunda ed. ár. (1906): Leiden: E. J. Brill (7+ 498 pp.) Reimpresión (1967): Leiden: E. J. Brill.

Tabula peutingeriana. Ed. lat. Scheyb, Franz Christoph von/Mannert, Konrad/Thiersch, Friedrich Wilhelm von (ed.) (1824): Tabula itineraria Peutingeriana. Lipsiae: Exhibet Libraria Hahniana (Königlich Bayerische Akademie der Wissenschaften).

Tabula peutingeriana. Ed. lat. Desjardins, Ernest (1869-1874): La table de Peutinger, d'après l'original conservé à Vienne. París: Hachette et cie.

Tabula peutingeriana. Ed. lat. Miller, Konrad (1887): Die Weltkarte des Castorius genannt die Peutingersche Tafel: einleitender Text. Ravensburg: O. Maier.

AL-'UDRī: Kitāb tarșī‘ al-ajbār. Ed. ár. al-Ahwānī, 'Abd al-'Azīz (1965): Ahmmad Ibn 'Umar Ibn Anas al-'Udrī. Nușūṣ 'an al-Andalus. Fragmentos geográfico-históricos de Al-Masālik ilà ğamĩ al-Mamālik. Madrid: Instituto Egipcio de Estudios Islámicos de Madrid (228 pp.).

AL-'UMARĪ: Masālik al-abṣār. Ed. ár. como reproducción árabe del ms. de Istambul, completado con otros mss. de El Cairo por: Sezgin, Fuat/Jokhosha, A./Neubauer, E. (19881989): Routes toward insight into the capital empires. Masālik al-abșār fìmamālik al-amșār. Ibn Faḍlallāh al-'Umarī, Šihāb al-Dìn Abū l-'Abbās Aḥmad Ibn Yahyà. Frankfurt-am-Main: Institute for the History of Arabic-Islamic Science (27 vols.). 


\section{REFERENCIAS A ENCICLOPEDIAS Y CATÁLOGOS}

BA: Lirola Delgado, Jorge (dir./ed.)(2004): Biblioteca de al-Andalus. Almería: Fundación Ibn Tufayl de Estudios Árabes, 2004-2012 (7 vols.).

$E I$ : Houtsma, M. Th. et al. (eds.) (1913-1938): The Encyclopcedia of Islam: A Dictionary of the Geography, ethnography and Biography of the Muhammadan Peoples. Leiden/Londres: E. J. Brill/Luzac (4 tomos + 5 suplementos). Reimpesión (1993): Leiden/New Yorl/Köln: E. J. Brill ( 8 tomos +1 suplementos).

$E I^{2}$ : BeARMAN, P. J./BianQuis, Th./Bosworth, C. et al. (eds.)( 1960-2005):Versión en francés: Encyclopédie de l'Islam, nouvelle èdition. Leiden: E. J. Brill (12 vols). Versión de los textos en inglés: The Encyclopaedia of Islam. 2nd edition. Leiden: E. J. Brill (12 vols.).

EIr: Encyclopcedia Iranica. Londres, 1982-. Encyclopcedia Iranica, online edition. Nueva York, 1996-. <http://www.iranicaonline.org/> (30 octubre 2017).

GAL: BrockelmanN, C. (1937-1949): Geschichte der arabischen Litteratur, Leiden: E.J. Brill (2 vols. + 3 suplementos). Reimpresión (1996): Leiden: E.J. Brill.

Bosworth, C. Edmund: "Ebn Kordādِbeh (or Korradādِbeh), Abu'l-Qāsem 'obayd-Allāh b. 'Abd-Allāh". EIr, vol. 8, 37-38. <http://www.iranicaonline.org/articles/ebn-kordadbeh> (30 octubre 2017).

Cour, A. (1927): "Al-Bakrī". EI', vol. 2, 6o6-6o7.

Dunlop, D. M. (1960): "Al-Balkַh̄ī, Abū Zayd Ahmmad b. Sahl”. EI², vol. 1, 1033-1034.

Guilliot, Cl. (2002): "Al-Warrāk, Mạ̣mūd b. (al-)Hasan”. EI ${ }^{2}$, vol. 11, 165-166.

HADJ-SADOK, M. (1971): “Ibn Khhurradād̄hbbih”. $E I^{2}$, vol. 3, 863.

Kramers, J. H. (1937): "Djughhrāfiyā". EI', vol. 9 (Suplemento 1), 61-73.

LÉvi-ProvenÇAL, É. (196o): "Abū 'Ubayd al-Bakrī”. $E I^{2}$, vol. 1, 159-161.

Lirola Delgado, J. (2009): “Al-Idrīsī, Abū 'Abd Allāh”. BA, vol. 6, 371-380.

Lirola Delgado, J. (2012): "Al-Bakrī, Abū 'Ubayd”. BA, vol. 1, 154-16o.

Lirola Delgado, J. (2012): "Al-'Udirī, Abū l-'Abbās". BA, vol. 7, 559-570.

MAQBUl AHMAD, S. (1965): "Djughrāfiyā", $E I^{2}$, vol. 2, 590-6o2.

Miquel, A. (1971): “Ibn Ḥawḳal, Abū l-Ḳāsim Muḥammad b. 'Alī al-Nāṣībī”. EI², vol. 3, 81o-811. MiQuel, A. (1978): “Al-Ișțaknhrī”. EI', vol. 4, 232-233.

Molina, L. (2002): "Al-'Uḍhrrī, Abū l-'Abbās Aḥmad b. 'Umar b. Anas, Ibn al-Dalā'î”. $E I^{2}$, vol. $10,837-838$.

OMAN, G. (1971): "Al-Idrīsī”. EI², vol. 3, 1058-1061.

Pellat, Charles (1991): "Al-Masālik wa-l-Mamālik". EI', vol. 6, 624-625.

Pellat, Charles (1993): "Al-Muhallabī, Abū l-Ḥusayn al-Hasan b. Aḥmad”. EI², vol. 8, 36o.

Pellat, Charles (2004): “Al-Djayhānī”. EI², vol. 12 (Suplemento), 264-266.

Pocklington, R. (2012): "Al-Warrāq, Muhammad". BA, vol. 7, 612-615.

SALIBI, K. S. (1979): "Ibn Faḍl Allāh al-'Umarī”. $E I^{2}$, vol. 3, 781-782.

SEYbold, C. F. (1979): “Al-Idrīsī". EI', vol. 3, 451-452.

VAn Arendonk, C. (1934a):"Ibn Ḥawḳal, Abū l-Ḳāsm (Muhammad)". EI', vol. 3, 383-4.

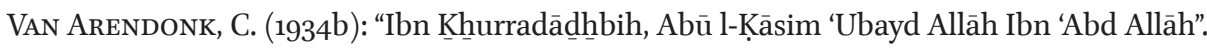
$E I^{1}$, vol. 3, 398 . 